\title{
GLOBALIZATION OF EQUITY MARKETS AND THE COST OF CAPITAL
}

\author{
René M. Stulz \\ Working Paper 7021 \\ http://www.nber.org/papers/w7021
NATIONAL BUREAU OF ECONOMIC RESEARCH
1050 Massachusetts Avenue
Cambridge, MA 02138
March 1999

I am grateful for research assistance from Ed Glidewell, Jan Jindra, and Doug Lee, for comments from Bernard Dumas, Peter Henry, Andrew Karolyi, Nils Tuchschmid, and Ingrid Werner, and participants at the NYSE-Bourse de Paris Conference on Global Equity Markets in Paris. I thank the NYSE and the Bourse de Paris for financial support. The views expressed in this paper are those of the authors and do not reflect those of the National Bureau of Economic Research.

(0) 1999 by René M. Stulz. All rights reserved. Short sections of text, not to exceed two paragraphs, may be quoted without explicit permission provided that full credit, including ${ }^{\circledR}$ notice, is given to the source. 
Globalization of Equity Markets and the Cost of Capital

René M. Stulz

NBER Working Paper No. 7021

March 1999

\section{ABSTRACT}

This paper examines the impact of globalization on the cost of equity capital. We argue that the cost of equity capital decreases because of globalization for two important reasons. First, the expected return that investors require to invest in equity to compensate them for the risk they bear generally falls. Second, the agency costs which make it harder and more expensive for firms to raise funds become less important. The existing empirical evidence is consistent with the theoretical prediction that globalization decreases the cost of capital, but the documented effects are lower than theory leads us to expect. We discuss various reasons for why this is the case.

René M. Stulz

Chair of Banking and Monetary Economics

Ohio State University

1775 College Road

Columbus, OH 43210-1399

and NBER

stulz@,cob.ohio-state.edu 
After World War II, most currencies were not convertible, so that investors could only invest in foreign markets if they could get access to often scarce foreign currencies. In addition to convertibility restrictions, most countries also had explicit restrictions on foreign investment. In some cases, foreign investors could not buy local shares. In other cases, domestic investors were not allowed to hold foreign shares. If foreign investors could buy local shares, they did not always have voting rights and often there was a limit on foreign ownership. Most countries had explicit foreign ownership limits of one type or another creating significant barriers to international investment. In addition to restrictions resulting from laws and regulations, there were other less formal obstacles to international investment. Foreign equity investment was also made difficult by political risk, inadequate institutions to deal with ownership of foreign shares, lack of accounting harmonization across countries, and obstacles to hedging foreign exchange rate risk.

Over the last fifty years, barriers to international investment have crumbled among developed economies and have fallen dramatically among many emerging markets. As a result of this evolution, U.S. investors can buy the securities of a large number of foreign countries with almost no restrictions. Corporations can choose where to raise funds and have access to both offshore and onshore markets. Asian investors now worry about how the U.S. markets performed while they were asleep because they believe that the fate of their markets during the day depends on what happened in New York over the previous twelve hours. Similarly, morning news shows in the U.S. routinely discuss the overnight performance of Asian markets and try to forecast the performance of U.S. markets from the overnight returns of the Nikkei and Hang Seng indices. Though finance academics have generally welcomed this process of globalization and emphasized its benefits to investors and corporations, many policymakers have questioned whether this process has gone too far and whether 
controls on capital flows should be reintroduced. The recent upheavals in Asia and Russia have led to the reimposition of some barriers to international investment.

In this paper, we evaluate how this process of globalization affects the cost of equity capital of companies. Though a firm's total cost of capital also depends on its cost of debt, the cost of debt depends in subtle ways on how a firm is taxed. By focusing on the cost of equity capital, we avoid dealing with complicated taxation issues. ${ }^{1}$ In Section I, we investigate how globalization affects the discount rate of a given stream of equity cash flows. We show that there are strong theoretical arguments for why this discount rate should fall when markets become more open to foreign investors. Such a fall in the discount rate means that both the value of equity and investment increase.

Neo-classical financial economists and a number of consulting firms would argue that what we call the discount rate is simply the cost of capital for an all-equity firm. However, managers and financial economists who emphasize the importance of information asymmetries and agency costs do not think about the cost of capital in this way. Rockfeller used to explain that his main problem in business was to raise capital. He generally found this to be an extremely difficult and costly process that prevented him from investing as much as he felt was worthwhile. ${ }^{2}$ There are two important reasons for this. First, managers are typically better informed about expected future cash flows than investors. This is the information asymmetry problem. Second, management has its own objectives

${ }^{1}$ See Ando and Auerbach (1988) for an analysis of the issues that arise when comparing the cost of capital across countries when taxes are taken into account. We ignore taxation of the cash flows to equity in this paper because these taxation issues are of secondary importance in our analysis.

2 "The hardest problem all through my business career was to obtain enough capital to do all the business I wanted to do and could do, given the necessary amount of money." Cited by Chernow (1997), p. 68. 
that may differ from those of investors. This is the agency costs problem. These two problems interact in important ways. Typically, management wants the firm to grow. As a result, managers and investors often disagree about expected cash flows. Because managers usually want to raise as much capital as they can, it will almost always be the case that investors do not believe that expected cash flows are as high as management forecasts. ${ }^{3}$ As a result, management cannot raise as much capital as it wants for new projects. Also, for existing firms, management may have to give up too much of the value of the firm to raise the capital it wants. Viewed from this perspective, a firm's cost of capital depends crucially on the firm's governance, which we define broadly as the set of mechanisms that affect how the information and agency costs problems impact firm value. Firms with poor governance are then firms where the information asymmetry and agency costs problems are important. Such firms find it more expensive to raise funds.

In Section II of the paper, we address the impact of governance on the cost of capital and argue that globalization affects firm governance in several ways. First, globalization means that new shareholders invest in a firm. In general, these investors have skills and information that enable them to monitor management in ways local investors could not. Second, globalization transforms the relationship between a firm and providers of capital. In small closed markets, there is little competition among suppliers of capital. A firm wanting to raise large amounts of capital faces the problem that few investors and institutions can help it do so. This increases transaction costs associated with raising capital and limits the types of securities that a firm can sell. Globalization creates competition among suppliers of capital. This reduces the cost of capital for firms both in that it reduces the rents that accrue to the capital providers and reduces transaction costs. Third,

\footnotetext{
${ }^{3}$ See Stulz (1990).
} 
globalization transforms the market for corporate control. A firm that is large in its local market might not be large in the world markets. A firm that is safe from takeovers in a closed local market is not safe in an open market. Therefore, globalization increases the monitoring of managers both from existing shareholders and from potential bidders. Fourth, globalization gives firms access to financial technology that enables them to raise funds using new securities and to manage their risks more effectively. Not all of these effects of globalization on governance are unambiguously positive. For instance, globalization can enable firms to break off existing relationships that constrained them from making poor investments. Further, new financial technologies can enable managers to pursue strategies that do not benefit the shareholders. We therefore attempt to evaluate the impact of globalization on governance taking into account both positive and negative effects.

In Section III, we review the existing evidence on the impact of globalization on the cost of capital and present some new evidence. We present a condition that must be met for globalization to decrease the cost of capital when investors have equal constant relative risk aversion across countries. We provide evidence that shows that this condition holds for all countries in our sample. In the U.S., the traditional approach to evaluate the discount rate is to look at the average of the rate of return on a broad-based market index for a long period of time. Unfortunately, this approach is not useful when a process of globalization is taking place because this approach assumes that the discount rate is constant. We therefore review alternative approaches to estimate the discount rate. In many ways, studies that look at returns around times of unexpected changes in the degree of globalization of a country or a firm can provide the best picture of the impact of globalization on the discount rate. These studies show that opening markets decreases the discount rate, but not as dramatically as theory would predict. 
In Section IV, we discuss possible reasons for why the impact of globalization on the cost of capital has not been as large as theory would suggest. We argue that the main explanation for this is that investors do not invest as much abroad as would be expected if they held the world market portfolio. We advance a number of alternative explanations for this phenomenon.

\section{Section I. The impact of the removal of barriers to international investment on the discount rate.}

In this section, we explore the impact of the removal of barriers to international investment on the cost of capital. To narrow the scope of the inquiry, we ignore exchange rates and assume that money markets are internationally integrated. In other words, we proceed as if there are one currency and one interest rate and focus on the question of how globalization of equity markets affects the cost of capital. By proceeding this way, we ignore an important aspect of globalization. If money markets are not integrated, the interest rate in a country has to be such that savings and investment are balanced. Consequently, the interest rate will unexpectedly increase as a country's investment opportunities unexpectedly improve. With globalization, savings and investment can differ within the country. This means that, everything else equals, interest rate volatility should fall. We completely ignore this effect of globalization on the volatility of interest rates and its consequences for the cost of capital in our analysis.

In a world where barriers to international investment are such that national capital markets are completely segmented from each other, investors in each country have to bear all the risk of the economic activities of that country. Investors in a country require a risk premium to bear this risk. This premium increases with the riskiness of the country's economic activities. Suppose that investors 
in each country are risk-averse and care only about the expected return of their invested wealth and the variance of that return. They therefore measure risk by the variance of the return of their portfolio. Furthermore, to simplify the exposition, we assume that all investors are the same within each country. In this case, as the return volatility of a country's market portfolio increases, the risk premium of the market portfolio, defined as the expected return on the market portfolio minus the risk-free rate, increases. If investors have the same constant coefficient of relative risk aversion, the risk premium on the market is the coefficient of relative risk aversion times the variance of the return on the market portfolio. As a result, a country where the variance of the return on the market portfolio is twice that in another country has a risk premium that is twice the risk premium of the other country.

If a country's investors only care about the expected return and the volatility of their invested wealth and that country's capital market is segmented from other capital markets, the capital asset pricing model (CAPM) holds for that country. Consequently, when investors evaluate the risk of a risky security, they do not worry about the risk of that security as a stand-alone security but instead about how this security contributes to the risk of their portfolio. Since all investors in a country are assumed to be the same, they hold the same portfolio of risky securities. This portfolio has to be the market portfolio, namely a portfolio that includes all the risky securities of a country in proportion to their market value. All investors therefore evaluate the risk of a security in terms of how it contributes to the risk of the market portfolio of their country. The measure of the contribution of the risk of a security to the risk of the market portfolio is the security's beta coefficient. The beta coefficient of a security is equal to the ratio of the covariance of the return of that security with the return of the market portfolio divided by the variance of the return of the market portfolio. A security 
that contributes more to the risk of the market portfolio has a higher beta. Since that security is riskier, it should receive a higher risk premium. With the CAPM, the expected return required by the market on a risky security is equal to the risk-free rate plus a risk premium equal to the beta coefficient of the security times the market's risk premium. When a firm considers whether to take on a project, the present value of the project for the shareholders is given by the expected cash flows they will receive from the project discounted at their required rate of return as determined by the CAPM. A decrease in the market's risk premium makes all projects whose return has a positive covariance with the return on the market portfolio more advantageous. Typically, projects have a positive covariance with the return on the market portfolio.

We now consider the impact on the cost of capital for the case where segmented countries decide to open up their markets to each other. ${ }^{4}$ To do so, we take the economic activities of the various countries as given. In other words, if a country has invested in the production of widgets, the payoff from that economic activity is assumed to be unchanged by globalization. This means that the expected value and the variance of the profits from producing widgets are not affected by globalization. As a country opens up its capital market to foreign investors and lets its residents invest abroad, the residents of the country no longer have to bear all the risks associated with the economic activities of the country. Foreign investors, by investing in the country, bear some of these risks. In exchange, domestic investors, by buying foreign securities, bear some foreign risks. For domestic investors, the benefit from bearing both domestic and foreign risks rather than only domestic risks is that some of these risks offset each other through the process of diversification. A country might have

${ }^{4}$ Subrahmanyam (1974) provides an analysis of the case where two segmented capital markets become one market. He shows that wealth does not necessarily increase in each country, but that welfare necessarily does for the utility functions he considers. 
bad news on one day, but another country might have good news. Because of diversification resulting from access to global capital markets, domestic investors can construct a portfolio of equities that has less risk for the same expected return.

To understand the impact of diversification when countries liberalize their capital markets, it is useful to consider an example. Assume for the purpose of this example that each country is small, that there are a large number of countries, that the return on each national market portfolio has the same expected value and variance, and that the return on the market portfolio in each country is uncorrelated with the return of the market portfolio in every other country. After all countries become open to each other, investors who care only about the expected return and the variance of the return of their portfolio hold the world market portfolio to take maximum advantage of the benefits from diversification. With our assumptions, the expected return of the invested wealth of an investor does not depend on how his wealth is invested across countries, but the variance of the return of the investor's invested wealth falls with the number of countries in which he invests. As the investor's portfolio becomes more and more diversified across countries, the variance of the return of his wealth becomes trivial. In the extreme case where the number of countries is extremely large and the return of the market portfolio of each country is independent of the return of the market portfolio of the other countries, the world market portfolio would have no risk and hence no risk premium.

If investors truly care only about the expected return and the variance of the return of their invested wealth, then when they have additional investment opportunities, they take advantage of them to hold portfolios that have a higher expected return for the same variance or have a lower variance for the same expected return. This means that in integrated markets investors hold an internationally diversified portfolio of risky securities and measure the risk of individual risky 
securities by how they contribute to the variance of the return of their internationally diversified portfolio. Since all investors are assumed to be the same, they invest their wealth in the same way and the country they come from is irrelevant. If all investors hold the same portfolio of risky assets, they have to hold the world market portfolio. As a result, the CAPM holds for all integrated markets together rather than on a country-by-country basis since investors hold securities from all these countries. It is useful to think of the equity markets that are integrated with each other as forming essentially one market which we call the global equity market. This means that the beta coefficient of a risky security is computed relative to the market portfolio for the global equity market, which we call the world market portfolio. With our example, if there are enough countries, the volatility of the world market portfolio becomes zero and consequently the beta of each security becomes zero. This would mean that the risk premium in each country would fall to zero since no country would contribute to the risk of the market portfolio.

It is unrealistic to think that all risks could be completely diversifiable internationally. In particular, business cycles cross country boundaries. Nevertheless, the example where all risks are diversifiable starkly shows that, in principle, globalization can decrease risk for the world equity market as a whole and hence reduce each country's cost of capital by making risks diversifiable that would not otherwise be diversifiable.

We now consider the impact of opening up a country's capital markets on its cost of capital more generally. Consider a small country whose equity markets are completely segmented from the equity markets abroad. Since the country is small, adding that country to the world equity markets does not increase the risk premium on the world market portfolio. Remember that our investors measure risk by the return variance of their portfolio. They are rewarded for bearing risk by the risk 
premium. The price per unit of risk is therefore the risk premium divided by the variance of the return. To eliminate the impact of differences in risk aversion, we assume that all investors in the world have the same constant relative risk aversion. With this assumption, the price of risk in that country before its market opens up is a constant which we denote by T. Consequently, the risk premium on the small country before integration is:

$$
\text { Risk premium before globalization }=\sigma_{\text {Small country }}^{2} * \mathrm{~T}
$$

where $\sigma_{\text {Small country }}^{2}$ is the small country's market portfolio return variance. We now consider the risk premium after globalization. Remember that after globalization, the small country's equity market becomes part of the global equity market. Denote the expected return of the world market portfolio by $\mathrm{E}\left(\mathrm{R}_{\mathrm{World}}\right)$. If we write $\mathrm{R}$ for the risk-free rate, the risk premium on the world market portfolio is $\mathrm{E}\left(\mathrm{R}_{\text {World }}\right)-\mathrm{R}$. The capital asset pricing model holds for the global equity market, so that the risk premium on a risky asset depends on its beta coefficient with respect to the world market portfolio:

$$
\begin{aligned}
\text { Risk premium after globalization } & =\beta_{\text {Small country }} *\left[\mathrm{E}\left(\mathrm{R}_{\text {World }}\right)-\mathrm{R}\right] \\
& =\rho \sigma_{\text {Small country }} \sigma_{\text {World }} * \mathrm{~T}
\end{aligned}
$$

$\sigma_{\text {World }}$ is the volatility of the return on the world market portfolio, $\sigma_{\text {Small country }}$ is the return volatility of the small country's market portfolio, and $\rho$ is the correlation coefficient between the return of the small country portfolio and the return of the world market portfolio. The beta of the 
small country market portfolio with respect to the world market portfolio, $\beta_{\text {world }}$, is defined as $\frac{\rho \sigma_{\text {World }} \sigma_{\text {Small Country }}}{\sigma_{\text {Small Country }}^{2}}$. The second line in equation (2) follows from the fact that the price of risk in the world equity markets is $\mathrm{T}$ and that all investors in the world are the same. It follows from a comparison of the risk premium before globalization and after globalization that a necessary and sufficient condition for globalization to reduce the risk premium of the small country is that:

$$
\left[\frac{\sigma_{\text {Small country }}}{\sigma_{\text {World }}}\right]>\rho
$$

This condition holds whenever an investor in the small country who has put all his wealth in the country's market portfolio can construct a portfolio that has a lower variance of return than the market portfolio of the small country by selling some of his holdings of the small country market portfolio and making a positive investment in the world market portfolio. It is possible that this condition would not hold for a specific country. Figure 1 shows when globalization could increase the cost of capital of a country. The reason why globalization might increase the cost of capital of a country is that in global markets, a country's risk premium depends on the covariance of that country's market portfolio return with the return of the world market portfolio. If this covariance is high, this means that the market portfolio of the country is risky from the perspective of the global markets. Hence, it is expected to earn a large risk premium which might exceed the risk premium it would be expected to earn if it was segmented from the global markets. If the return of the market 
portfolio of the small country is uncorrelated with the return of the world market portfolio, then the small country's market portfolio is not expected to earn a risk premium when it is integrated in the global market. Consequently, as long as the correlation between the small country's market portfolio return and the return of the world market portfolio is not too high or the volatility of the small country's market portfolio is not too low, the small country's risk premium falls when it joins the global equity market.

Figure 2 plots the maximum allowable correlation coefficient between the small country and the world market for integration to decrease the cost of capital. It is immediately obvious that if the correlation is negative, globalization always decreases the cost of capital. Though some correlations are negative, this case does not seem generally relevant. Note, however, that globalization decreases the cost of capital over a wide range where the correlation is positive provided that the return volatility of the world market portfolio does not exceed the return volatility of the small country market portfolio by too much. A case that is generally relevant is the one where the volatility of the world market portfolio is lower than the volatility of the small country. In this case, irrespective of the correlation coefficient, globalization necessarily decreases the cost of capital of the small country. We will see in Section III that when the condition given by equation (3) is applied to a large number of countries, there is not a single country where a case can be made that globalization increases the cost of capital.

We now consider the question of whether a large country that belongs to the global equity market has a smaller risk premium than if it did not. To answer this question, we have to take into account the fact that the risk premium of the global equity market depends on whether the country belongs to that market. With our assumption that all investors are the same and have constant relative 
risk aversion, the larger country has a lower risk premium when it belongs to the global market than when it is segmented from these markets provided that investors in the large country can construct a lower variance portfolio by taking a long position in the equity of the other countries that belong to the global market portfolio. In this case, both the larger country and the other countries in the global market portfolio benefit from belonging to the global equity market.

Our analysis so far has focused on the cost of capital for the country as a whole. If the cost of capital in a country falls because of globalization, this means that the value-weighted cost of capital across firms in that country falls as well..$^{5}$ It is possible, however, for globalization to decrease the cost of capital for a country but increase the cost of capital for some firms within that country. Before globalization, the CAPM holds for the country. Denote the country risk premium before globalization as $\lambda_{\text {Small country }}$. The risk premium for a firm's equity before globalization is given by:

$$
\begin{aligned}
& \text { Risk premium of firm } i \text { before globalization } \\
& =\beta_{i}^{\text {Small country }} * \lambda_{\text {Small country }}
\end{aligned}
$$

where $\beta_{i}^{\text {Small country }}$ is the beta coefficient of firm $i$ before globalization. This beta coefficient is therefore the ratio of the covariance between the return of the $i$-th firm and the return of the small country market portfolio divided by the variance of the small country market portfolio. After globalization, the risk premium of firm $i$ becomes:

$$
\begin{aligned}
& \text { Risk premium of firm } i \text { after globalization } \\
& =\beta_{i}{ }^{\text {World market }} * \lambda_{\text {World market }}
\end{aligned}
$$
markets.

${ }^{5}$ See Stulz (1995) for an analysis of how to compute the cost of capital of a firm in global 
Now, the beta coefficient is computed with respect to the world market portfolio and the risk premium of the market is the risk premium for the world market portfolio. It is possible for firm $i$ to have a low beta coefficient with respect to the small country market portfolio and a high beta coefficient with respect to the world market portfolio. An example of such a situation is the following. Suppose that firm $i$ is small enough that it does not affect the distribution of the return of the market portfolio in the small country. Assume that firm $i$ has a low correlation with respect to the small country market portfolio but a high correlation with respect to the world market portfolio. In this case, firm $i$ has a low risk premium before globalization but a high risk premium afterwards. However, when globalization reduces the risk premium of a country's market portfolio, it must be the case that the market-value weighted average of the firms' risk premiums falls. This means that a firm with a cost of capital increase because of globalization is the exception rather than the rule when globalization decreases the cost of capital of its country.

In addition to considering the impact of a country's capital market liberalization on the cost of capital of firms within the country, it is also important to consider the impact on a firm's cost of capital if that firm can access global markets but the other firms in its country cannot. Equation (4) gives us the firm's risk premium when it does not have access to the world capital markets. In this case, the firm's cost of capital is determined by its local market. When the firm accesses the world capital markets, its cost of capital is given by world capital markets as shown in equation (5). If a firm has a low beta with respect to the world market portfolio but a high beta with respect to its local market, the fall in the cost of capital from globalization is substantial. Suppose that a firm has a beta of one with respect to its country's market portfolio and that this country has a risk premium of $20 \%$. In this case, the firm's cost of capital is the risk-free rate, assumed to be 5\%, plus $20 \%$. If the firm's 
risk is diversifiable in global markets, the firm's equity cost of capital becomes the risk-free rate. In other words, by accessing world markets this firm experiences a reduction in its cost of capital of $80 \%$. In general, firms will have some non-diversifiable risks in world markets, so that the cost of capital does not decrease that much.

To obtain the result that globalization decreases the cost of capital under circumstances that are empirically plausible, we made a number of assumptions. We now consider whether any of these assumptions are essential for our results. We simplified our analysis by assuming that investors are similar within and across countries. Such an assumption is important in the following sense. In our analysis of the small country that becomes global, the country's cost of capital would obviously increase if investors in that country are close to risk-neutral while investors in the global equity market are much more risk-averse. However, it seems unlikely that investors' risk preferences differ systematically across countries. One could argue that investors in more developed financial markets might act as if they are less risk-averse because they have more opportunities to hedge against risks, but except for this, there is no good reason to suspect that differences in risk-tolerance across countries are important. We assumed that investors have constant relative risk aversion. This assumption is not essential to our analysis. The assumption that investors care only about the expected return and the variance of their portfolio is not essential either.

Our analysis assumed that the rate of interest is constant as capital market segmentation changes. Basak (1996) discusses how globalization can increase the rate of interest. To see this, consider two otherwise similar countries, but one country's equity market is closed. Keeping the rate of interest constant, we know that everybody is better off. This implies that investors would want to consume more now as well as in the future. If the goods available now for consumption are fixed, the 
interest rate has to increase to induce investors to avoid consuming more now. For this interest rate effect to be important, it has to be that the country that opens up its equity market is large compared to the world. This assumption is reasonable whenever a small country opens its equity markets.

By taking the interest rate and the distribution of payoffs to economic activities to be constant, we ignored how globalization changes economic activities. As Obstfeld (1994) shows, globalization allows countries to specialize more and undertake riskier projects because individuals in a country can diversify risks by investing abroad. However, as diversification decreases the cost of capital, it also increases investment. In the short-run, resources are fixed. An increase in the rate of interest can make resources available for investment that otherwise would be consumed. Again, though, if the country whose market opens up is small, there is no reason to think that this will have a noticeable impact on interest rates in the world. Prices of investment goods can also increase. Since a country's stock of investment goods is given at a point in time, the short-term impact of globalization on prices of investment goods within a country could be significant. Over time, the price impact would fall because of imports.

In our analysis, we have focused on the impact of globalization on the cost of capital. It is important to remember that globalization affects welfare as well as the cost of capital. Though the impact of globalization on the cost of capital is theoretically ambiguous, this is not so for the impact of globalization on welfare. ${ }^{6}$ Consider again our small country. As that country joins the global equity market, its cost of capital increases or decreases. If the cost of capital of that country increases, the

\footnotetext{
${ }^{6}$ See Subrahmanyam (1975). Again, however, the work of Basak (1996) shows that the interest rate increase associated with globalization can decrease a country's welfare. This only happens if the country that liberalizes is large in the sense that its actions have a significant impact on the world interest rate and if this country borrows for current consumption.
} 
value of its market portfolio falls so that globalization makes investors in that country financially worse off. We saw that this outcome is unlikely, but suppose it did occur. In this case, investors in the small country get to invest their wealth in the world market portfolio. Because of the benefits from international diversification, these investors can invest in a portfolio that has the same variance as the small country market portfolio but has a higher expected return. It turns out that for reasonable utility functions, investors in the small country who have a choice between having the small country remain segmented or becoming part of the global equity market, choose globalization because of the risk-sharing that globalization enables them to achieve even though their wealth falls.

The fact that globalization leads to better opportunities to share risks for individuals in different countries implies that even though globalization can decrease wealth in a country or decrease the value of a firm, the equity value of the augmented global market is always higher than the sum of the equity values of the countries that joined the global market and the countries that belonged to that market already. In other words, globalization necessarily increases wealth. This means that it is always possible to redistribute the wealth increase resulting from globalization so that every investor benefits. In the language of economists, globalization is Pareto-optimal. Therefore, it can take place in such a way that everybody is better off and nobody is worse off.

\section{Section II. Globalization, governance, and financial services.}

The theoretical arguments for why globalization decreases the discount rate of investors are compelling, but they do not capture the whole impact of globalization on the cost of capital. To understand this, let's focus on a firm that has to raise equity to finance investment. In many ways, the ability of firms to raise equity is a paradox. With an equity issue, the firm receives cash without a 
contractual agreement to give anything back. For equity financing to be possible, shareholders have to believe that they will receive a cash flow that makes their investment worthwhile. The rate at which shareholders discount the expected cash flow is the one discussed in Section I. However, the ability of the firm to raise funds depends crucially on the cash flow shareholders expect to receive. As discussed in the introduction, managers face difficulties in convincing shareholders that they can expect to receive a sufficiently high expected cash flow to make it worthwhile to buy the equity. ${ }^{7}$ This is because managers have information that shareholders do not have about the firm's investments and can alter projects to benefit them at the expense of shareholders. It is therefore possible for a firm to have good projects but be unable to finance them because its managers cannot convince shareholders that these projects are worthwhile. Though we focus first on a firm where managers are in power, many of the issues that we discuss are the same if a large shareholder is in power instead. We address the case where a large shareholder is in power next.

Consider the management of a firm that has valuable projects viewed from the perspective of management. In other words, if management could convince investors that the cash flows that will accrue to investors are those that management expects, the shareholders would benefit if the firm were able to invest in these projects. Managers will generally have difficulties convincing investors of the value of projects because they benefit from investment even if the projects are not as good as they say. Managers benefit if the firm grows. This leads them to want to invest in marginal projects if better projects are not available rather than pay out larger dividends. Shareholders can reduce management's ability to invest inappropriately by monitoring managers, so that actions by managers that do not benefit investors are likely to be discovered. Managers will be penalized for taking such

\footnotetext{
${ }^{7}$ See Stulz (1990) for more details and references.
} 
actions, and steps will be taken to force managers to change them.

Monitoring is unlikely to be sufficient to ensure that managers maximize firm value for the investors. Managers also have to have incentives to do so. In general, however, both incentives and monitoring are required to obtain the best outcome for minority shareholders. There are at least three reasons why monitoring alone is not sufficient. First, if outsiders could find out and understand everything managers do and know, there would be no need for managers. Managers are needed because delegation from the owners of the firm is necessary. Consequently, monitoring is imperfect. Second, monitoring is expensive. This limits the amount of monitoring. In some cases, monitoring is so expensive that it does not take place at all. For instance, management may claim that a discovery has high value, but to verify this claim might be too expensive. Third, because monitoring is imperfect and expensive, it tends to take place when bad outcomes occur. If the firm loses money, investors will expend resources to figure out what is happening. It is much harder for outsiders to figure out whether managers did not take actions that would have made a successful firm even more successful.

Incentives can lead managers to take actions that maximize shareholder wealth even when no monitoring takes place. Nevertheless, the impact of incentives is limited. Not all managers are equally good, so that some managers might not benefit much from incentives and would be removed if monitored. Managers may benefit from disguising poor performance. Also, managers can gain by taking actions that maintain and increase firm size even if they do not increase the stock price because their perks depend on firm size. Finally, opportunities for managers to favor friends or large shareholders can be profitable for them at the expense of minority shareholders.

Let's consider how monitoring of management takes place and how it is affected by 
globalization. ${ }^{8}$ We consider in turn the main mechanisms used to monitor management:

1) The board of directors. In principle, a firm's board of directors is the most direct monitoring mechanism of management. Managers report to the board and the board can fire management. Board members have a duty to be informed about what management is doing. The difficulty with this is that managers generally determine the composition of the board when the firm has diffuse shareholders. This limits the board's ability to monitor management. Having a board that lacks credibility is not an issue for a firm that does not have to raise funds. However, if the firm wants to raise funds on the capital markets, it becomes an important issue because a weak board is less likely to correct the actions of managers or replace managers if needed, so that investors expect lower cash flows from a project if it is undertaken by a firm with a weak board. To access global markets, investors in these markets have to have confidence that the use of the funds they provide will be monitored. This will lead to boards that are more independent of management and play a more active role.

2) The capital markets. Managers are monitored when they go to capital markets. ${ }^{9}$ To sell securities, managers have to hire investment bankers who play a key certification role. The reputation of these investment bankers is at stake in the issuance process. To access global markets, firms have to use investment bankers with a reputation in these markets. This leads to the monitoring of management by investment bankers who have different skills, information, and incentives. While local investment bankers might notice some problems in a firm, global investment bankers will generally (1997).

\footnotetext{
${ }^{8}$ For a recent review of the literature on corporate governance, see Shleifer and Vishny
}

${ }^{9}$ See Easterbrook (1984). 
notice other problems. A firm trying to access global markets therefore has to pass a hurdle that firms that only raise funds at home do not have to pass.

3) The legal system. The legal system plays two roles. ${ }^{10}$ First, it limits the rights of management. With a poor legal system, managers can steal from shareholders. As the legal system improves, this becomes more difficult. Second, the legal system provides a mechanism for investors to monitor management and exercise their rights. As shareholders discover actions by management that hurt them, they can use the legal system to force management to rescind such actions. With the globalization of financial markets, firms from countries with poor protection of minority shareholders that raise funds and list in countries with better protection of minority shareholders expose themselves to legal actions from investors in these countries. As a result, minority shareholders are better protected in these firms. An example of this is the case of Velcro Industries reported by La Porta, Lopez-de-Silanes, Shleifer, and Vishny (1999). This firm was incorporated in the Netherlands Antilles and listed on the Montreal Stock Exchange. Two-thirds of the shares were in the hands of the Cripps family which tried to reduce the share price by slashing earnings to buy out minority shareholders cheap. The stock price fell from $\$ 30$ in 1998 to $\$ 12$ within a year, but rebounded to $\$ 20$ in 1990 when the Cripps family made an offer to repurchase minority shares at $\$ 21$. An American minority shareholder sued in New York. According to Forbes (May 23, 1994) "When a New York judge ruled that the U.S. was the proper jurisdiction, secretive Sir Humphrey Cripps decided to call off his offer rather than go under the light of U.S. court of law." By 1994, the shares were trading at \$57. Besides leading to greater monitoring of firms that participate in the international markets, globalization also puts pressure on countries to improve their legal system so that they can better participate in the

\footnotetext{
${ }^{10}$ See Shleifer and Vishny (1997).
} 
global markets.

4) Active shareholders. Small shareholders have little incentive to monitor management. Even if monitoring would lead to an improvement in management's policies that increase firm value, the benefit to small shareholders would be limited compared to the costs. Large shareholders benefit much more from monitoring. As a result, the management of a firm with large shareholders is monitored more closely. The difficulty with the monitoring by large shareholders is that these shareholders might use their stake to obtain benefits from management that do not accrue to the other shareholders. The most valuable large shareholders to a corporation are those who have specialized skills that enable them to give valuable input to management. Globalization makes it possible for investors from other countries to take large stakes in a firm and monitor management. An example of active foreign investors is the case of Olivetti, which was the fourth largest public company in Italy in 1995. It was making huge losses in its PC division. Its Chairman, Carlo de Benedetti, had to raise funds from international institutional investors in December 1995, giving them a $70 \%$ stake in the company. He promised to solve the problems of the PC division. By September 1996, the new investors thought he was floundering. The share price was at 726 Lira. They forced de Benedetti out and eventually forced the company to divest its losing assets. By the time of the announcement of the last major divestiture at the beginning of 1998, the share price was at 1,958 Lira, having more than doubled (New York Times, March 3, 1998).

5) The market for corporate control. Ultimately, the market for corporate control makes it possible to remove management if it does not maximize shareholder wealth. ${ }^{11}$ If firms can be taken over, investors can make large profits by acquiring information about possible targets. This leads to

\footnotetext{
${ }^{11}$ See Jensen and Ruback (1983).
} 
monitoring of management even if no takeover takes place since management knows that if it performs poorly, it could become a takeover target. Opening up a capital market to foreign investors immediately creates a much larger pool of investors that can compete for control of firms within that market. This leads to greater competition for control which benefits existing shareholders directly.

6) Disclosure. Disclosure of information by firms is required by laws and regulations. However, firms would disclose information even if they were not required to do so. This is because otherwise they would face difficulties raising funds from the public capital markets and would be able to raise funds only from financial intermediaries. When a firm raises funds from a financial intermediary, it can provide information directly to the financial intermediary, so that public disclosures can be replaced by private disclosures. When a firm raises funds from public markets, it has to provide information more readily. However, in addition, investors are concerned about the availability of information in the future. With greater disclosure, it becomes less costly to monitor management since it has to give more information about its performance. The problem is that it is difficult for a firm to commit to disclosure. The choice of a regulatory environment is a mechanism for firms to commit to disclosure, as is the listing on an exchange. Through globalization, firms can commit to higher disclosure standards by seeking additional listings on exchanges that have higher standards than their local market. Firms benefit from this greater disclosure if it reveals that they have the good prospects their management believes that they have. Since only firms whose management expects to benefit from greater disclosure list on stricter exchanges, the announcement that a firm will list on a stricter exchange is good news. Cantale (1998) and Fuerst (1998) develop theoretical models 
where firms reveal their good prospects by listing abroad. ${ }^{12}$

In this analysis, globalization increases the monitoring of management and hence increases firm value. Yet, based on our analysis, one might conclude that globalization increases the monitoring of management only for those firms that decide to participate in the global capital markets. This is not the case, however. Once a firm has a choice between participating in global capital markets and not participating, it reveals information about itself if it does not participate. To see this, consider the case of disclosure. Firms that want to participate in global markets have to meet disclosure standards that allow them to compete for funds on these markets. If a firm does not decide to meet such disclosure standards, investors can only conclude that the firm does not do so because adhering to such standards would reveal adverse information about the firm. Consequently, firms that stay local and keep adhering to poorer disclosure standards reveal themselves as firms that are worth less than previously thought. Viewed this way, globalization puts pressure on all firms through greater monitoring of management.

Our discussion has focused on the case where management is in control. One would generally view such a situation as typical in the U.S. and the U.K. As Laporta, Lopez-Silanes and Shleifer (1999) show, however, such a situation is not typical in many other countries. They demonstrate that outside of the U.S. and the U.K. a more typical situation is one where a large shareholder controls the firm. We saw earlier in this section that large shareholders have greater incentives to monitor management. However, large shareholders also have greater incentives to force management to take

${ }^{12}$ See also Huddard, Hughes, and Brunnermeister (1998) for an analysis that focuses on the how the competition among exchanges for trading volume impacts disclosure requirements. They argue that this competition leads to a race to the top rather than to the bottom in terms of disclosure requirements. 
actions that benefit them at the expense of other shareholders and other investors. This creates a problem for firms in accessing capital markets. For instance, investors who buy equity in a firm controlled by a large shareholder will discount the price they are willing to pay to reflect the fact that the firm's profits might be siphoned off to companies controlled by the large shareholder. This discount might be large enough that the firm effectively cannot raise new funds. Further, should it raise new funds, the large shareholders would lose money if they did not siphon off profits since they sold equity at a price that reflects this dilution. To avoid this problem, minority shareholders have to be protected. Rather than monitoring management, these shareholders want to monitor the large shareholder. They can do so using the mechanisms discussed above except for the board of directors, since the large shareholder will control the board of directors. By listing on exchanges with high standards for minority shareholder protection, a firm commits to respecting the rights of these shareholders. To the extent that the local exchange does not have such high standards, globalization enables firms to seek listings on foreign exchanges which have high standards, thereby increasing firm value by insuring that the firm's policies are more likely to increase shareholder wealth and by making it easier for the firm to raise funds. The same argument can be made for listing in countries with strong minority shareholder rights to the extent that shareholders from these countries benefit from these rights when they buy foreign shares. ${ }^{13}$

In the analysis of Section I, we ignored the costs of buying and selling securities. Globalization affects these costs for a firm and this impact increases firm value directly and indirectly. Amihud and

${ }^{13}$ In Cantale (1998), managers have private benefits from control that become smaller when they list on a stricter exchange because of the greater scrutiny. Coffee (1999) provides an analysis of the legal implications of a U.S. listing for a foreign firm and how minority shareholders benefit from such a listing. 
Mendelson (1986) among others show that the bid-ask spread affects the market's required rate of return on securities. The reasoning is that if investors have to pay more to transact a security, they have to be compensated with a greater expected return before transaction costs to offset these costs. With globalization, one expects the bid-ask spread on securities to decrease for several reasons. First, directly related to our analysis of governance, the greater disclosure associated with globalization at the firm level directly implies that there are fewer valuable opportunities for insider trading. This means that investors and market makers who do not have access to inside information worry less about being taken advantage of by insiders when they trade, so that more investors and market makers are willing to transact in a firm's securities. This leads to greater liquidity and a lower bid-ask spread. Evidence on the link between disclosure and the cost of capital is provided by Botosan (1997). She shows empirically for the U.S. that firms with limited analyst following that disclose more have a lower cost of capital. Smith and Sofianos (1997) show that firms that list abroad experience an increase in volume, even on their home market, which is consistent with the argument that globalization leads to greater liquidity and hence a lower cost of capital. Second, globalization means greater competition in market-making and investment banking services. Firms that enter the global capital markets have access to investment banks that can compete for their business and hence lower prices. These firms can also choose to list on exchanges that are more efficient, thereby reducing the cost of transacting their securities.

The greater liquidity that results from globalization has an indirect impact on the monitoring of management. First, with greater liquidity, the market for a firm's equity becomes more efficient in that it better reflects information about the firm. This makes the firm's stock price more informative and hence more useful in monitoring management. Second, greater liquidity makes it easier for 
investors to accumulate positions in a stock and to sell these positions as well. Bhide (1993) argues that greater liquidity generally means less monitoring of management since shareholders can sell their shares if they do not agree with management's policies easily. The argument is that in a liquid market shareholders who do not agree with management's policies can sell their shares rather than try to convince management to adopt different policies. Maug (1998) points out, however, that liquidity is essential for large shareholders to build positions. Hence, with liquid markets, investors who want the firm to change its policies or who want to acquire the firm can do so.

Access to global financial markets enables firms to take advantage of greater competition for investment banking services. This allows them to save costs when they issue new securities. However, it also allows them to access different types of services and products. In particular, it enables them to take advantage of new financial technologies and new financial products. To develop new financial technologies and new financial products, investment banks generally require economies of scale that are present in large financial centers but not available in smaller ones. For instance, these firms develop expertise in financial products and techniques used to manage risks. Access to such products and techniques enables firms to reduce their risk. A direct consequence of better risk management is that it becomes easier to evaluate management. ${ }^{14}$ This is because risk management allows the firm to make adverse developments that do not result from management's actions less likely, so that if adverse developments occur, they are more likely to result from managerial mistakes.

One way to capture the impact of globalization on the cost of capital is as follows. We can divide total firm value into three pieces. The first piece is the present value of the cash flows that accrue to the capital providers who do not receive benefits from control. The second piece consists

${ }^{14}$ See Diamond (1984) for an early analysis of this point. 
of the value of the benefits from control. ${ }^{15}$ When management is in charge, it gets to take actions that benefit management instead of benefitting shareholders. Large shareholders get these benefits when they control the firm. The third piece corresponds to the deadweight costs resulting from the agency costs and information asymmetries that lead to benefits from control. With our analysis, globalization increases the present value of the cash flows that accrue to the capital providers both by decreasing the discount rate of these cash flows for the reasons discussed in Section I and by increasing the cash flows they receive. The cash flows shareholders receive increase because globalization enables firms to finance valuable projects, decreases the benefits from control, and decreases the deadweight costs resulting from agency costs and information asymmetries.

It is not the case, however, that all effects of globalization necessarily increase the monitoring of management in the short-run. The reason for this is that globalization can disrupt existing relationships within a country that led to the monitoring of management or large shareholders. For instance, consider the case of Japan. In the Japanese economy, monitoring historically took place primarily through banks and through the keiretsu. Banks held equity stakes in their customers and played a much more active role in the financing and the governance of firms than would be the case in U.S. banks. As a result, Japan was viewed as having a bank-centered governance system. Such a system was contrasted with the U.S. system, where the market for corporate control has a central role in the monitoring of managers. Globalization had a dramatic impact on the financing and the governance of Japanese firms: it enabled firms to raise funds outside of Japan ${ }^{16}$ Firms found that

${ }^{15}$ There is a growing empirical literature that evaluates these benefits from control across countries. See Shleifer and Vishny (1997) for references. These benefits can be substantial as evidenced by Zingales (1994) in the case of Italy.

${ }^{16}$ See Kang, Kim, Park, and Stulz (1995). 
doing this was cheaper because of competition among investment banks that did not exist within Japan. This weakened domestic banks and forced them to reduce their fees for issuing securities. Further, to keep issuing securities at home, these banks were forced to relax issuing standards on the domestic public debt market. Before 1980, Japanese firms could not raise debt on public markets because of informal and formal restrictions. This benefitted banks since firms had to use banks to obtain debt finance. As competition from foreign markets increased, the standards that firms had to meet to issue public debt in Japan were lowered, so that by the 1990s almost all firms were eligible to issue public debt. ${ }^{17}$ Because of globalization, Japanese banks lost much of their power in that their client firms became able to raise funds publicly. A bank can monitor management only to the extent that it can threaten to withhold funds. This threat weakened in Japan as a result of globalization. Unfortunately, at least in the short-run, Japanese firms continued to be controlled by Japanese corporate shareholders, so that the benefits of globalization in terms of a larger pool of active shareholders and potential bidders could not manifest itself. In the case of Japan, therefore, globalization in the short-run reduced the power of banks, but did not replace that power by the power of the market. At the same time, however, it is becoming clear that firms have to change because of globalization and that some firms are evolving toward Western-style corporate governance where more attention is paid to stock prices.

\section{Section III. The empirical evidence on the impact of globalization on the cost of capital.}

We saw in the previous section that globalization decreases a country's cost of capital as long

\footnotetext{
${ }^{17}$ See Rosenbluth (1989) for an analysis of the impact of foreign competition on regulation in Japan.
} 
as the investors of that country can create a portfolio that has a lower variance by making positive investments in other countries. In this section, we examine the empirical evidence of the impact of globalization on the cost of capital. We examine this issue in three steps. First, we discuss the problems of traditional approaches of estimating the risk premium using time-series data to evaluate the impact of globalization on the cost of capital. Second, we discuss indirect approaches to assess the impact of capital market liberalizations on the cost of capital. Finding that these indirect approaches generally detect a significant but small impact of globalization on the cost of capital at the country as well as at the firm level, we then address the issue in the last part of this section of why the measured impact is not higher.

\section{A. Globalization, the CAPM, and a simple test of whether globalization reduces the cost of capital.}

In the analysis of Section I, we assumed that investors only care about the expected return of their portfolio and the variance of that return. We further assumed that a market was either completely segmented from the other markets or fully integrated in the global markets. With these assumptions, the CAPM holds where the market portfolio is the value-weighted portfolio of all securities that investors have access to. The analysis becomes substantially more complicated if we allow for cases where investors in a country face some barriers to international investment, but these barriers are not such that the country is completely segmented. ${ }^{18}$ The analysis of Section I raises two questions. First, does the CAPM hold among the countries whose markets are integrated? Second, is it generally the case that the condition we derived in Section I according to which globalization

\footnotetext{
${ }^{18}$ See Errunza and Losq (1985), Eun and Janakiramanan (1986), and Stulz (1981).
} 
lowers the cost of capital holds? We answer these two questions in this section.

Tests of the CAPM in an international setting have been conducted in two ways. First, there have been tests of the CAPM using country portfolios. These tests have been surprisingly supportive of versions of the CAPM that allow for a time-varying risk premium. In particular, Harvey (1991) provides evidence that is consistent with the CAPM holding internationally using a large number of countries. He finds, however, that the return of the Japanese portfolio is inconsistent with the CAPM over his sample period because of the extremely large return of Japanese stocks in the 1980s. Using a different approach, DeSantis and Gerard (1997) also find results supportive of the international CAPM. Chan, Karolyi and Stulz (1992) conduct a study where they consider the U.S., Japanese and the Morgan Stanley Europe, Asia and Far East indices. In that study, they find evidence supportive of the CAPM as well. They show that the risk premium on the U.S. portfolio depends on the covariance of the return of that portfolio with the return on the foreign index. In other words, the risk premium on the U.S. market portfolio depends on how the U.S. portfolio is correlated with foreign stocks. One would expect such a result if the CAPM holds for Japan and the U.S. jointly since in this case the beta of the U.S. market portfolio with the world market portfolio would depend on its covariance with the return of the Japanese portfolio.

Throughout this paper, we have ignored foreign exchange and the peculiar problems it can create when considering the pricing of risky assets. ${ }^{19}$ The issue that arises is that foreign exchange rate risk can be priced. If it is not priced, investors choose to have no foreign exchange exposures. The difficulty with this is that investors long in a foreign stock have to short that currency to eliminate the foreign exchange rate risk. This requires domestic investors to be long the currency. In equilibrium,

${ }^{19}$ See Adler and Dumas (1981) for a review and analysis of these issues. 
the long holdings of domestic investors have to equal the short holdings of foreign investors. The risk premium on foreign exchange exposure makes this equilibrium possible. Dumas and Solnik (1995) provide evidence supportive of the view that exchange rate risk affects the pricing of risky assets.

Though the CAPM fares well when a study examines country portfolios, it fares less well when a study focuses on pricing portfolios of stocks within countries as well as across countries. The difficulty that arises then is that the problems the CAPM faces when used in one country obviously do not disappear when one studies a number of countries. This means that the anomalies that are inconsistent with the CAPM within one country, such as the size effect and the book-to-market effect are present across countries. For instance, Korajczyk and Viallet (1989) show that a world CAPM understates the expected returns of small firms across countries. Fama and French (1998) show that value stocks earn a premium across countries and make the case for a world value factor.

The evidence on the CAPM shows clearly, however, that countries that are integrated in world markets have a risk premium that depends on their covariances with the world market portfolio. This is the key intuition of the CAPM on which we relied in Section I to argue that globalization decreases the cost of capital. We saw that this intuition led to the condition that the cost of capital of a country is lower if it is part of the global capital market than if it is segmented from it as long as the variance of the return of the market portfolio of that country is greater than the covariance of the return of that country with the world market portfolio. Table I provides evidence on that condition for 37 countries for a ten-year period ending on October 28, 1998. As is evidenced in the table, there is not a single country where the condition for a decrease in the cost of capital is not met. It is important to note, however, that we derived our condition under the assumption that 
differences in relative risk aversion across countries can be ignored and that the distribution of the return of the world market portfolio is given.

\section{B. Time-series evidence.}

The traditional approach to evaluating the risk premium on a market consists of computing the average excess return on the market over a long period of time. For instance, it is common in the U.S. to use past excess returns on the U.S. stock market since the 1920s. The argument for proceeding this way is the presumption that the future is likely to be similar to the past. One has to use long periods of time because the stock market is volatile. Over shorter periods of time, one might conclude that the risk premium is either negative because the market fell, or extremely high because the market increased dramatically. For instance, if one uses rolling twenty year periods to estimate the risk premium, one would conclude that the risk premium increased recently. From 1976 to 1995 , the estimate of the risk premium for the U.S. using the Ibbotson data is $7.31 \%$, but from 1978 to 1997 it is $9.36 \%$.

A market's capitalization is the present value of the cash flows shareholders will receive from the securities traded in that market, where the discount rate is the one computed using the risk premium of the market. This implies that if the cash flows shareholders expect remain unchanged but the risk premium falls, the market experiences high returns because its capitalization increases. This negative relation between equity values and the risk premium makes it harder to estimate the risk premium using historical data. Consequently, in periods when the risk premium is falling, equity values increase, so that one might conclude, based on equity returns, that the risk premium is high. Alternatively, if the risk premium is increasing during a period, stock returns are lower than they 
would be with a constant risk premium and one might conclude that the risk premium is falling.

Using past returns to estimate the risk premium is a good approach when one believes that the risk premium is relatively stable over time. In this case, the longer the period over which one estimates the risk premium, the better the estimate one obtains. Unfortunately, the variance of stock returns is high enough that one reaches different conclusions about the size of the risk premium depending on the estimation period even when one uses fairly long periods of time. For instance, the U.S. risk premium estimated over the last seventy years is substantially higher than the U.S. risk premium estimated over the last two hundred years. Economists have spent a tremendous amount of effort trying to understand why the risk premium on U.S. equity is as high as it is, arguing that the degree of risk-aversion of individuals consistent with the size of the U.S. risk premium is too high to make sense. ${ }^{20}$ However, this problem is much more substantial if one looks at the risk premium over the last seventy years than if one looks at the risk premium over the last two hundred years.

There is little reason to believe, however, that the risk premium is stable over long periods of time. From our discussion in the previous section, we know that there are good reasons for the risk premium to be related to the variance of returns. This variance changes over time. The market portfolio changes over time as well. In segmented markets, the relevant market portfolio to estimate the risk premium is the market portfolio of a country. Consequently, if the U.S. forms a closed market, the risk premium that is relevant for the U.S. depends on the variance of the U.S. market portfolio. In integrated markets, the world market risk premium depends on the variance of the world market portfolio. With constant relative risk aversion, the world market risk premium is a constant fraction of the world market return variance. As markets become more integrated because barriers

\footnotetext{
${ }^{20}$ See Abel (1991).
} 
to international investment fall, more countries become part of the world market portfolio.

As the world market portfolio includes more countries, one expects its variance to fall because of the benefits of international diversification. However, this depends partly on the variance of the countries that are added to the world market portfolio and on the correlation of these countries with the existing world market portfolio as we saw in the previous section. Figure 3 shows how adding a country to the world market portfolio affects the volatility of the return of that portfolio (its standard deviation), assuming that the world market portfolio volatility is $15 \%$ before the new country is added. We see that the world market portfolio volatility falls as long as the correlation between the market portfolio and the new country is not too high. If the return of the new country has a positive correlation with the return of the world market portfolio, adding the new country increases the volatility of the world market portfolio if the volatility of the added country is high enough.

Figure 4 shows a plot of the volatility of the world market portfolio since the 1970s. Several important lessons can be obtained for this plot. First, volatility is volatile. This makes it difficult to use volatility to draw inferences about the evolution of the risk premium. Second, the plot shows two periods of relatively low volatility, namely the 1970s and the 1990s. The market portfolio of the 1970s is essentially a market portfolio of developed economies while the market portfolio of the 1990s also includes emerging markets. Consequently, this is consistent with the view that the risk of emerging markets is largely diversifiable in the world market portfolio and that volatility was low among the developed markets. It turns out that during the 1990s, the volatility of the S\&P500 is only slightly higher than the volatility of the world market portfolio. The problem is therefore to explain why volatility would have been low in general during that period of time. Greater risk-sharing and 
participation in equity markets can lead to lower volatility. Unfortunately, we have neither good models nor empirical evidence on this issue. Third, with constant relative risk aversion, one would expect a decrease in the cost of capital during the 1990s because of the lower volatility. ${ }^{21}$

Globalization has taken place over the last forty years, so that if the theoretical analysis about the impact of globalization on the cost of capital is right, one would expect that the cost of capital decreased over the last forty years. Since, using the time-series average of the risk premium, one needs long periods of time to estimate the cost of capital, it is hopeless to estimate the impact of globalization on the cost of capital with an approach that uses time-series averages. One possible solution is to use an explicit model of the determinants of the risk premium that allows for the impact of globalization. As of now, this approach has not been followed. Consequently, we lack research that uses the time-series of stock returns to identify the impact of globalization on the risk premium.

\section{Event-study approaches.}

We saw that it is difficult to evaluate the impact of globalization on the cost of capital using the traditional approach of estimating the mean excess return on the market because this approach requires a long period of time where one expects the cost of capital to be constant. Stock prices are, everything else equal, negatively related to the cost of capital. Consequently, an unexpected decrease in barriers to international investment in a country should lead to an unexpected increase in stock prices. This suggests that one might be able to find out the impact of globalization on the cost of capital by investigating the impact of globalization events on the equity capitalization of firms and

\footnotetext{
${ }^{21}$ Interestingly, Pastor and Stambaugh (1998) examine the risk premium using econometric techniques that allow for structural breaks and identify a decrease in the cost of capital in the early 1990s.
} 
countries.

In corporate finance, it is common to investigate the impact of corporate events on equity by estimating the return of firms over the day or days that event takes place. For instance, such an approach is used to estimate the impact of equity issues on firm value. If markets incorporate information into prices efficiently, all the information contained in an equity issue should affect firm value immediately. Consequently, studies that evaluate the impact of equity issues do so by focusing on the stock return of the issuing firm on the day that the issue is announced or even, in some cases, on the minutes around the time that the issue is announced. When a firm announces an equity issue, the impact of the announcement on the firm's equity is affected by idiosyncratic characteristics of the firm and of the announcement. Hence, focusing on the announcement for an individual firm does not produce a reliable estimate of the impact of equity issues for a firm. However, if we look at the average impact of equity issues across a large number of firms, one expects that the idiosyncratic characteristics of each issuing firm and each issue average out in the sample. This approach to estimating the impact of corporate events is called an event study.

If equity markets incorporate information efficiently, one expects that events that lead investors to believe that an equity market will be more open to foreign investors and that investors in a country will be better able to invest abroad should have an immediate impact on equity value. In other words, events that lead investors to believe that a country will become better integrated in a world market directly affect equity prices in that country. Hence, one can apply the methodology of event studies to globalization events.

Henry (1998) provides an event study that investigates the stock market impact of capital market liberalizations. He uses a sample of 12 countries that liberalize. In his first test, he considers 
the impact of liberalization on a period that starts four months before the announcement and ends three months after the announcement. Over that period, stock returns are higher by $4.6 \%$ per month on average, for a total cumulative abnormal return of $36.8 \%$. He then proceeds to investigate whether this impact of globalization still holds when he controls for various variables that influence stock returns, in particular macroeconomic variables. As a result, the impact of liberalization falls somewhat, to about $30 \%$, but the impact is still statistically as well as economically significant. His evidence therefore shows that liberalization increases wealth substantially.

What does an increase in stock prices of $30 \%$ imply for the cost of capital? The value of equity is the present value of cash flows that will accrue to the shareholders. We can therefore consider the following experiment that produces an estimate of the impact of globalization on the cost of capital for the countries of Henry's sample. A simple valuation model in corporate finance is Gordon's growth model. This model assumes that cash flows to shareholders correspond to dividends and that dividends have a constant growth rate. The model then uses a perpetuity formula to value the future dividends. With this model, the value of equity is equal to $d /(r-\pi)$, where $d$ is the dividend payment at the end of the period, $\mathrm{r}$ is the cost of capital and $\pi$ is the growth rate of dividends. Suppose one takes $d$ and $\pi$ as given. In this case, we can reverse-engineer the impact on the cost of capital from liberalization from the price change:

$$
\text { Price after - Price before }=\frac{d}{r_{\text {After }}-\pi}-\frac{d}{r_{\text {Before }}-\pi}
$$

With Henry's study, we have the price change in percentage terms, which we define as $\Delta$. We can solve the above equation to obtain: 


$$
\mathrm{r}_{\mathrm{A}}=\left(\frac{1}{1+\Delta}\right) * \mathrm{r}_{\mathrm{B}}+\left(\frac{\Delta}{1+\Delta}\right) * \pi
$$

We can use this equation to obtain the cost of capital impact. If the cost of capital before liberalization is $20 \%$ and the growth rate of dividends is $5 \%$, the cost of capital falls to $16.5 \%$ if the percentage change in the equity capitalization is $30 \%$. Figure 5 shows that the impact of liberalization on the cost of capital assuming a percentage change in the equity capitalization of $30 \%$ is mostly driven by the cost of capital before liberalization. The greater the cost of capital before liberalization, the larger the fall in the cost of capital that results from liberalization. This is because the weight of the growth of dividends in equation (7) is less than the weight of the cost of capital before the liberalization as long as the percentage price increase is less than $100 \%$.

The estimate for the fall in the cost of capital obtained from Henry's study has to be interpreted with some caution. First, we keep the growth rate of dividends constant as liberalization takes place. One would expect liberalization to lead to higher growth and hence a higher growth rate of dividends. This effect would therefore lead to a lower estimate of the change in the cost of capital. Second, to the extent that countries liberalize after their stock market has done well, Henry's estimate could overstate the magnitude of the gain from liberalization. Third, Henry does not include all liberalization events, which might understate the total impact of liberalization. Fourth, the approach suffers from the problem that the sample of liberalization events is small, so that the assumptions generally required for event studies do not hold and one cannot be confident that the results are not affected by idiosyncratic noise in country returns.

Bekaert and Harvey (1998) have an alternative approach to estimate the change in the cost 
of capital from liberalizations. To understand this approach, suppose that the Gordon growth model holds, so that the value of a firm is $\mathrm{d} /(\mathrm{r}-\pi)$. The dividend yield is the ratio of the dividend to the equity capitalization. Consequently, if the Gordon growth model holds, the dividend yield is $\mathrm{d} /[\mathrm{d} /(\mathrm{r}-\pi)]$, or $r-\pi$. If the dividend growth model holds and if the expected rate of growth of dividends is constant as liberalization takes place, then the change in the dividend yield following a liberalization corresponds exactly to the change in the cost of capital:

$$
\begin{aligned}
& \text { Dividend yield after - Dividend yield before } \\
& \qquad=r_{\text {After }}-r_{\text {Before }}
\end{aligned}
$$

Bekaert and Harvey exploit this result to estimate the impact of liberalization on the cost of capital. To do this, they use a sample of twenty emerging markets. They focus mostly on two types of liberalization events, the creation of a country fund and the initiation of the first ADR program by a firm in the country. With both of these events, securities in a country become available to foreign investors.

Ideally, if the Gordon growth model holds and the cost of capital is constant both before and after liberalization, all one would need to do to find out the change in the cost of capital due to the liberalization is to subtract the dividend yield after the liberalization from the dividend yield before the liberalization. There are several problems with such an approach. First, expected returns are not constant. Hence, the dividend yield might increase because expected returns increase even though the liberalization lowers the dividend yield. Second, data are noisy and the valuation model need not be correct for every stock price. As a result, the dividend yield at a point in time after liberalization might not be a good estimate of the dividend after liberalization because of noisy stock prices. Third, there 
are often multiple liberalization events. These difficulties require the use of a regression model that captures changes in the average dividend yield. Bekaert and Harvey use a sophisticated regression model where they allow a number of control variables to affect the dividend yield. With this model, they then estimate the impact of liberalization on the dividend yield. They find that liberalization decreases the dividend yield, which implies that it decreases the cost of capital. Their estimates of the impact are small. For ADR introductions, they find an impact that ranges from five basis points to 14 basis points. None of these impacts is significant. For country fund introductions, their estimates range from 16 to 57 basis points. All these estimates are significant. Depending on the specification they use, the authors find the impact of liberalization decreases the dividend yield from five to 90 basis points.

The Bekaert and Harvey study provides evidence of a decrease in the cost of capital following liberalization, but their estimated effects are small. These estimates rely on important assumptions. First, the estimates require a valuation model. Though the Gordon model itself is not necessarily required, models that more explicitly allow for a role of uncertainty in valuation generally make the equity capitalization depend on other variables that might be affected by liberalization. Second, the dividend yield growth as well as the payout ratio are likely to be affected by liberalization. An increase in the dividend growth rate would lead to an overestimate of the cost of capital after liberalization. Third, it is difficult to date liberalization. To the extent that liberalization dates are measured imprecisely, this problem biases the coefficient estimate for the impact of liberalization. Fourth, some variables that the authors control for are likely to be proxies for the degree of liberalization, which could lead to further bias.

If none of the firms in a country have access to international capital markets, the initiation of 
an ADR program by a firm in that country is evidence of liberalization of the capital market of that country. The early ADR initiations in a country are therefore viewed as liberalization events. As a firm in a country undertakes an ADR program, the cost of capital of the whole country can be affected if the introduction of the ADR program is viewed as evidence of liberalization for the country. Nevertheless, one would expect the primary impact of the initiation of an ADR program to be on the cost of capital of the firm that undertakes such a program. As a result, there has been a large number of studies that investigate the stock-price impact of ADR introductions. Karolyi (1998) provides a detailed review of these studies.

From our earlier analysis, we would expect that a firm that succeeds in having its equity valued at the global market cost of capital rather than the cost of capital of a segmented market would typically experience a substantial increase in value. As an example, suppose that the risk premium of the country is $20 \%$, the firm has a beta with respect to the country market portfolio of one, the growth of dividends is $4 \%$, and the risk-free rate is $5 \%$. Suppose that the risk of the firm is diversifiable in world markets, so that the firm has a world beta of zero. In this case, if the firm gets to unexpectedly access the world markets, its value would increase by a dramatic 2,000\%! Yet, empirical studies have not found evidence of large increases in firm value by focusing on a narrow window around the announcement of the ADR program or the listing of the ADRs. Perhaps even more puzzling, there is not complete agreement across studies on even the sign of the impact on firm value of the initiation of an ADR program. Recent studies have larger samples and more precise dating than earlier studies. Further, while earlier studies typically used monthly returns, some of the more recent studies use daily returns. Foerster and Karolyi (1999) and Miller (1998) investigate both the return around the announcement of an ADR program and the return around the day when the 
actual listing takes place. They find positive returns both around the announcement date and around the listing date. However, these returns are small. Foerster and Karolyi (1999) examine 153 ADR listings on NASDAQ, AMEX, and NYSE from 1976 to 1992. They find an abnormal return during the listing week of $1.2 \%$. For 45 listings, they also have an announcement date. For the announcement date, they find an insignificant positive abnormal return of $0.2 \%$. Miller (1998) finds an average announcement abnormal return of $1.04 \%$ for a sample of 125 announcements from 1985 to 1995. Miller's sample includes all ADRs, including Level I and Rule 144a. In his study, the average announcement abnormal return for the 53 ADRs listed on NYSE or NASDAQ is $2.63 \%$. He differentiates between firms from emerging markets and firms from developed markets. To the extent that emerging markets have more barriers to international investment than developed markets, one would expect a greater abnormal return for firms from emerging markets. He finds an announcement return of $1.54 \%$ for firms from emerging markets and of $0.87 \%$ for firms from developed markets. The difference between the two is not significant, however.

Even though Miller (1998) interprets his evidence from the perspective that listing shares on a foreign market relaxes barriers to international investment, it is important to note that his evidence is fully supportive of models such as those of Cantale (1998) and Fuerst (1998) that demonstrate that management signals its quality by listing on stricter exchanges and that listing on stricter exchanges increases shareholder wealth because it reduces private benefits from control. From this perspective, one would expect a larger stock-price reaction for listings on stricter exchanges and a larger stockprice reaction for firms coming from environments with looser disclosure standards and less protection of minority shareholders. This suggests higher abnormal returns for listing on the NYSE than for listing on other exchanges or NASDAQ and higher abnormal returns for firms listing from 
emerging markets where protection of minority shareholders is weaker than in other markets. This is exactly what Miller (1998) finds. Cantale (1998) investigates the stock-price reaction to the announcement that a firm from continental Europe or the UK intends to list on the NYSE, the London Stock Exchange, or the Paris Stock Exchange. He argues that the disclosure requirements are strictest on the NYSE, followed by the London Stock Exchange and the Paris Stock Exchange. He finds that 34 continental European firms listing on the NYSE experience an average abnormal return of 3.7\%; 46 continental European firms listing on the London Stock Exchange have an average abnormal return of 2.14\%; finally, 22 continental European firms listing on the Paris Stock Exchange experience an abnormal return of $1.15 \%$. All abnormal returns are significant and significantly different from each other.

Both Foerster and Karolyi (1999) and Errunza and Miller (1998) estimate returns before and after the initiation of an ADR program. Strikingly, Foerster and Karolyi find that firms that list experience an unexpected increase in their stock price of $19 \%$ for the year before the listing. This unexpected increase is followed, however, by an unexpected decrease of $14 \%$ in the year after listing. It is interesting to note that lower returns after listing have been documented before in the domestic context, so that low returns after listing in the case of Foerster and Karolyi (1999) may have nothing to do with the fact that the listing is an ADR listing but may have everything to do with the fact that firms list following exceptional performance. ${ }^{22}$ Errunza and Miller (1998) report an unexpected increase in the stock price of $8.06 \%$ for the six months preceding the announcement. For the six months following the announcement month, they find that their sample firms outperform by $2.28 \%$ comparable firms that do not announce an ADR program, but this result is not significant. In contrast

\footnotetext{
${ }^{22}$ See Dharan and Ikenberry (1995).
} 
to Foerster and Karolyi, Errunza and Miller look at longer periods before and after the announcement month. They look at a period that goes from the 36 months before the announcement to seven months before the announcement. For that period, they report an abnormal return of $34.39 \%$ for the firms that start an ADR program compared to firms in the same country of similar size that do not. They then look at a period that goes from seven months after the announcement to 36 months after the announcement. For that period, they find an abnormal return of $-3.10 \%$ that is not significant. Errunza and Miller interpret the lower returns of firms in the period that follows the ADR introduction relative to the period before the ADR introduction as evidence of a decrease in the cost of capital. The problem with this interpretation is that the direct prediction of the theory is that the firms with an ADR program should have a lower return than the firms that do not have such a program. Their study does not make it possible to say much on this issue. Their estimate of $-3.10 \%$ corresponds to a lower cost of capital of 127 basis points per year if it can be used as an estimate of the difference in the cost of capital between firms with ADR programs and without ADR programs. This difference in cost of capital is not statistically significant. Errunza and Miller also use the dividend yield approach of Bekaert and Harvey. Using this approach, they find a drop of the dividend yield of 66 basis points. This drop is not statistically significant. They show, however, that the dividend yield falls more for firms that provide more diversification for U.S. investors.

Listing an ADR changes the exposure of a firm to its own country market index and to the U.S. market index. Foerster and Karolyi (1999) show that a firm that lists an ADR experiences a clear decrease in its exposure to its own market and a less convincing increase in its exposure to the U.S. market. Karolyi (1998) uses a model where the risk premium of a firm's equity is its local beta times the local market risk premium plus its U.S. beta times the U.S. market risk premium. With such a 
model, taking into account the beta changes that accompany an ADR listing, he finds that on average the cost of capital declines by 114 basis points for the sample of firms in Foerster and Karolyi (1999) which mostly contains firms from developed markets. Surprisingly, Urias (1996) finds, using a similar approach, that firms that access global markets from some emerging markets actually experience an increase in the cost of capital.

In Section II, we argued that an important implication of access to global markets is greater liquidity. A number of studies have documented that the effects discussed there take place. Foerster and Karolyi (1996) examine post-listing volume, quotes and prices for a sample of 52 Canadian stocks that list on the NYSE, AMEX and NASDAQ from 1981 to 1990. They find that volume increases as a result. They also find that spreads and liquidity decrease. Domowitz, Glen and Madhavan (1998) show evidence of greater competition for order flow in the case of Mexican ADRs. Using a large sample, Smith and Sofianos (1997) find that firms that access global markets experience an increase in volume on their home market as well as on the market that they access. All this evidence shows that listing abroad increases liquidity. It is important to note, however, that listing on a foreign exchange can affect liquidity for reasons other than those discussed in Section II. In particular, listing in New York means that trading shares becomes possible for a longer period of time if the home market of the firm has different trading hours. This means that investors can sell shares more easily if they unexpectedly need cash outside the trading hours of the home market. This makes shares more attractive.

At the firm level, it is possible to conduct an analysis that directly compares the valuation of firms that have ADR programs and firms that do not. In other words, using known valuation ratios, one can find out whether ADR firms are valued more than non-ADR firms within a country. Logue 
and Sundaram (1996) provide a study that looks at valuation ratios, but rather than comparing valuation ratios directly, they consider changes in valuation ratios around the listing month. They consider price-to-book, price-to-cash earnings, and price-to-earnings ratios. Their conclusion is that these ratios increase for firms that list ADRs relative to comparable firms that do not over a period overlapping the month of listing. This increase in valuation ratios is consistent with a decrease in the cost of capital.

\section{Section IV. Why is there a paradox?}

It is clear from theory that a country that liberalizes its capital markets can experience a large decrease in its cost of capital if the correlation of its market portfolio with the world market portfolio is not too large or if its volatility is larger than the volatility of the world market portfolio. These conditions are met for the countries that are used in the studies that we discussed. Further, it is also clear from theory that firms from segmented markets that succeed in accessing the global capital markets should face a much lower cost of capital if their return has a low correlation with the world market portfolio but a high correlation with the local market. Yet, the studies that consider the impact of liberalization on the cost of capital only find a small but significant impact.

The studies we considered all investigate how stock prices react to globalization. This immediately suggests a reason why they might find smaller effects than expected. If financial markets are efficient, we expect these markets to incorporate information in prices immediately. Consequently, when a country liberalizes or a firm accesses global capital markets, it is possible that the market already expected this event to happen to some degree. In the extreme case where the market knows that a firm will undertake an ADR program, the impact of that program on shareholder wealth will 
be trivial. The same holds for a country's liberalization. Viewed from this perspective, event studies have a fundamental problem. If globalization is so advantageous that it becomes largely predictable, the event studies will never find that it has an impact. The country studies find some impact, but to understand the implication of that impact for the cost of capital one has to understand the extent to which the liberalization is anticipated. This is hard to determine. To understand the importance of this point, suppose that the market expects a liberalization next month with probability 0.9 . If the liberalized country has a cost of capital that is $1,000 \mathrm{bp}$. less because of liberalization, the stock-price impact of the decision to liberalize corresponds to a decrease in the cost of capital of $0.1 * 1,000 \mathrm{bp}$., or $100 \mathrm{bp}$. Hence, an increase in stock prices could be consistent with a wide variety of changes in the cost of capital depending on the degree to which liberalization is anticipated. The impact of anticipation on studies that focus on the dividend yield is more complex, but whenever there is anticipation, these studies underestimate the impact of liberalization on the cost of capital. The same argument can be made for studies that focus on the introduction of ADR programs.

Though anticipation leads to the underestimation of the impact of globalization with the existing empirical studies, this is not the only reason why the impact of globalization is not as large as one might expect. The theoretical analyses make the assumption that a country liberalizes or a firm accesses global capital markets in such a way that they are immediately completely integrated in world markets. This is rarely the case. A well-documented empirical regularity in international finance is that investors are not as well-diversified internationally as predicted by the analysis of Section I and that 
they invest too much in their home country. ${ }^{23}$ As an example, ${ }^{24}$ in 1996 , U.S. investors held $90 \%$ of the value of their stock portfolio in U.S. stocks. At that time, however, U.S. stocks represented less than half of the world market capitalization of stocks. Consequently, if U.S. investors had been holding the world market portfolio of stocks, their holdings of U.S. stocks would have represented less than $50 \%$ of their holdings of stocks. The extent of the home bias seems to have fallen for U.S. investors before the recent bull market. In 1987, U.S. investors held $96.2 \%$ of their stock holdings in U.S. stocks. This home bias exists in all foreign countries for which statistics on ownership are available. Table II provides further evidence on the home bias.

Many theories attempt to explain the existence of the home bias. Though rules and laws limiting foreign portfolio investment have decreased, there are still many restrictions and additional costs to investing abroad. Interestingly, however, trading securities abroad is no longer necessary to get the benefits from international diversification. Errunza, Hogan, and Hung (1999) show that the benefits from international diversification can be obtained by holding foreign securities that trade in the U.S. either directly, as ADRs or listed foreign stocks, or in closed-end funds. Other reasons for the home bias have been advanced. In particular, authors have argued that information asymmetries between domestic and foreign investors, the existence of different consumption baskets, political risk, and behavioral biases can lead to differences in portfolios and can make portfolios biased toward domestic assets. ${ }^{25}$ Some of these explanations imply that investors do not invest abroad because they

${ }^{23}$ See Cooper and Kaplanis (1994), French and Poterba (1991), Kang and Stulz (1997), and Tesar and Werner (1995).

${ }^{24}$ See Tesar and Werner (1998) for these numbers.

${ }^{25}$ See Kang and Stulz (1997) for a discussion of these various explanations and references. 
do not know they would benefit or simply do not want to do so. For instance, Merton (1987) develops a model where investors invest in shares they know about. Investors who know little about foreign shares do not invest in them. Other explanations of the home bias lead to the conclusion that investors stay away more from some countries than from others. For instance, political risk is more important in some countries than in others. The informational advantage of home country investors depends on the disclosure and regulatory environment of a country. Consequently, depending on the institutions of the country that liberalizes, it could be that a country liberalizes but nobody comes to invest. If a country liberalizes, but markets expect that investors will never take advantage of the liberalization, then the liberalization does not affect the cost of capital. If a firm starts an ADR program but foreign investors do not hold the ADRs, much of the benefit of the program will fail to materialize. In support of this view, Foerster and Karolyi (1999) show that the stock-price impact of an ADR program depends on how it broadens the shareholder base.

To understand the implications of the home bias on the cost of capital, suppose that investors care only about the expected return and the variance of their portfolio and that they have constant relative risk tolerance. We have two countries, a small country and the rest of the world. For simplicity, we assume that the market portfolio of the small country and of the rest of the world are uncorrelated. There are no formal barriers to international investment, but some investors in the small country do not invest abroad and some investors in the rest of the world do not invest in the small country. We do not model the reason why investors do not hold foreign securities. Rather, we follow Merton (1987) and assume that some investors do not hold some securities because they do not know about them. This amounts to attributing the home bias to ignorance or an unmodeled behavioral bias. The Appendix provides the details of the model. In Figure 6, we show how the cost of capital of a 
country is affected by the extent of the home bias of its investors and of the home bias of foreign investors. It is clear from the figure that the impact of globalization on the cost of capital depends crucially on the extent of the home bias. As the home bias falls, the cost of capital falls. It could therefore be the case that a country opens up its markets but the home bias effect is strong enough that, as a result, there would be little impact on the cost of capital. At the same time, however, the figure shows the limits of the home bias argument. With our assumptions, the impact of foreign investors buying local shares on the local cost of capital falls quickly as the proportion of shares held by foreign investors increases. Hence, it could well be that in many cases, the home bias, large as it may be, is small enough to enable firms to capture most of the cost of capital benefit of globalization.

\section{Section V. Conclusion.}

We saw in this paper that there are compelling theoretical arguments for globalization to reduce the cost of capital. There are two main channels through which this reduction in the cost of capital occurs. The first channel is that globalization reduces the discount rate investors charge. The second channel is that globalization increases the cash flows investors expect to receive by increasing the monitoring of management and controlling shareholders. When we turned to empirical evidence, however, we saw that this evidence is limited and shows that the effect of globalization on the cost of capital is significant but small. We then argued that one important reason why the impact has been small is the existence of the home bias. For globalization to reduce the cost of capital, the shareholder base has to become truly global. This does not occur by decree. As a result, globalization is not an event but a process. Investors have to be convinced to take advantage of it. Further research should help to provide a better understanding of this process. 


\section{References}

Abel, Andrew, 1991, The equity premium puzzle, FRB-Philadelphia - Business Review, 3-14.

Ando, Albert, and Alan J. Auerbach, 1988, The cost of capital in the United States and Japan: A comparison, Journal of the Japanese and International Economies 2, 135-158.

Adler, Michael, and Bernard Dumas, 1983, International portfolio selection and corporation finance: A synthesis, Journal of Finance 46, 925-984.

Amihud, Yacov, and Haim Mendelson, 1986, Asset pricing and the bid-ask spread, Journal of Financial Economics 17, 223-249.

Basak, Suleyman, 1996, An intertemporal model of international capital market segmentation, Journal of Financial and Quantitative Analysis 31, 161-188.

Bekaert, Geert, and Campbell R. Harvey, 1995, Time-varying world market integration, Journal of Finance 50, 403-444.

Bekaert, Geert, and Campbell R. Harvey, 1998, Foreign speculators and emerging equity markets, unpublished working paper, Duke University, Chapel Hill, NC.

Berle, Adolf, and Gardiner Means, 1932, The modern corporation and private property, MacMillan, New York, NY.

Bhide, Amar, 1993, The hidden cost of stock market liquidity, Journal of Financial Economics 34, $31-51$.

Botosan, Christine A., 1997, Disclosure level and the cost of equity capital, The Accounting Review 72, 323-349.

Campollo-Palmer, 1997, Equity investment in emerging markets, NYSE Conference on the Globalization of Financial Markets, Cancun, Mexico. 
Cantale, Salvatore, 1998, The choice of a foreign market as a signal, Unpublished Working Paper, A.B. Freeman School of Business, Tulane University, New Orleans, LA.

Chan, K.C., G. Andrew Karolyi, and René M. Stulz, 1992, Global financial markets and the risk premium on U.S. equity, Journal of Financial Economics 32, 137-167.

Chernow, Ron, 1998, Titan: The life of John D. Rockfeller, Sr., Random House, New York, NY.

Coffee, John C. Jr., 1999, The future as history: The prospects for global convergence in corporate governance and its implications, The Center for Law and Economic Studies, Working Paper No. 144, Columbia University School of Law, New York, NY 10027.

Cooper, Ian A., and Evi. Kaplanis, 1994, Home bias in equity portfolios, inflation hedging and international capital market equilibrium, Review of Financial Studies 7, 45-60.

DeSantis, Giorgio, and Bruno Gerard, 1997, International asset pricing and portfolio diversification with time-varying risk, Journal of Finance 52, 1881-1913.

Dharan, Bala G., and David Ikenberry, 1995, The long-run negative drift of post-listing stock returns, Journal of Finance 50, 1547-1574.

Diamond, Douglas, 1984, Financial intermediation and delegated monitoring, Review of Economic Studies 51, 393-414.

Domowitz, Ian, Jack Glen, and Ananth Madhavan, 1998, International cross-listing and order flow migration: Evidence from an emerging market, Journal of Finance 53, 2001-2028.

Dumas, Bernard, and Bruno Solnik, 1995, The world price of foreign exchange risk, Journal of Finance 50, 445-479.

Easterbrook, Frank, 1984, Two agency-cost explanations of dividends, American Economic Review $74,650-659$. 
Errunza, Vihang, and Etienne Losq, 1985, International asset pricing under mild segmentation: Theory and test, Journal of Finance 40, 105-124.

Errunza, Vihang, Ked Hogan, and Mao-Wei Hung, 1999, Can the gains from international diversification be achieved without trading abroad?, Journal of Finance, forthcoming.

Errunza, Vihang, and Darius P. Miller, 1998, Market segmentation and the cost of capital in international equity markets, unpublished working paper, Texas A\&M University, College Station, TX.

Eun, Cheol, and S. Janakiramanan, 1986, A model of international asset pricing with a constraint on the foreign equity ownership, Journal of Finance 41, 897-914.

Fama, Eugene F, and Kenneth R. French, 1998, Value versus growth: The international evidence, Journal of Finance 53, 1975-2000.

Feldstein, M., and C. Horioka, 1980, Domestic saving and international capital flows, Economic Journal 90, 314-329.

Foerster, Stephen R., and G. Andrew Karolyi, 1996, Multimarket trading and liquidity: A transactions data analysis of Canada-US interlistings, working paper, The Ohio State University, Columbus, $\mathrm{OH}$.

Foerster, Stephen R., and G. Andrew Karolyi, 1999, The effects of market segmentation and investor recognition on asset prices: Evidence from foreign stocks listing in the U.S., Journal of Finance, forthcoming.

French, K., and J. Poterba, 1991, International diversification and international equity markets, The American Economic Review 81, p. 222-226.

Fuerst, O., 1998, A theoretical analysis of the investor protection regulations: Argument for global 
listing of stocks, Working Paper, Yale School of Management, New Haven, CN.

Harvey, Campbell, R., 1991, The world price of covariance risk, Journal of Finance 46, 111-158.

Henry, Peter B., 1998, Stock market liberalization, economic reform, and emerging market prices, unpublished working paper, Stanford University, Palo Alto, CA.

Huddart, Steven, John S. Hughes, and Markus Brunnermeister, 1998, Disclosure requirements and stock exchange listing choice in an international context, unpublished working paper, Duke University, Durham, NC.

Dharan, Bala G., and David Ikenberry, 1995, The long-run negative drift of post-listing stock returns, Journal of Finance 50, 1547-1574.

Jensen, Michael, C., and Richard Ruback, 1983, The market for corporate control, Journal of Financial Economics 11, 5-50.

Kadlec, B. Gregory, and John J. McConnell, 1994, The effects of market segmentation and illiquidity on asset prices: Evidence from exchange listings, Journal of Finance 49, 611-636.

Kang, Jun-Koo, and René M. Stulz, 1997, Why is there a home bias? An analysis of foreign portfolio equity ownership in Japan, Journal of Financial Economics 46, 2-28.

Kang, Jun-Koo, Yong-Cheol Kim, K. Park, and René M. Stulz, 1995, An analysis of the wealth effects of Japanese offshore dollar-denominated convertible and warrant bond issues, Journal of Financial and Quantitative Analysis 30, 257-270.

Karolyi, G. Andrew, 1998, Why do companies list shares abroad? A survey of the evidence and its managerial implications, New York University Salomon Brothers Center, New York, NY.

Kim, E. Han, and Vijay Singal, 1998, Stock market openings: Experience of emerging economies, Unpublished working paper, Pamplin College of Business, Virginia Tech, Blacksburg, VA. 
Korajczyk, Robert, and Claude Viallet, 1989, An empirical investigation of international asset pricing, Review of Financial Studies 2, 553-585.

LaPorta, Rafael, Florencio Lopez-de-Silanes, Andrei Shleifer, and Robert W. Vishny, 1997, Legal determinants of external finance, Journal of Finance 52, 1131-1150.

LaPorta, Rafael, Florencio Lopez-de-Silanes, Andrei Shleifer, and Robert W. Vishny, 1999, Agency problems and dividend policies around the world, Journal of Finance, forthcoming.

LaPorta, Rafael, Florencio Lopez-de-Silanes, and Andrei Shleifer, 1999, Corporate ownership around the world, Journal of Finance, forthcoming.

Logue, Dennis, and Anat Sundaram, 1996, Valuation effects of foreign company listings on U.S. exchanges, Journal of International Business Studies 27, 67-88.

Maug, Ernst, 1998, Large shareholders as monitors: Is there a tradeoff between liquidity and control?, Journal of Finance 53, 65-98.

Merton, Robert, 1987, A simple model of capital market equilibrium with incomplete information, Journal of Finance 42, 483-510.

Miller, Darius P., 1998, The market reaction to international cross-listings: Evidence from Depositary Receipts, Journal of Financial Economics, forthcoming.

Obstfeld, Maurice, 1994, Risk-taking, global diversification, and growth, American Economic Review 84, 1310-1329.

Pastor, Lubos, and Robert F. Stambaugh, 1998, The equity premium and structural breaks, working paper, Rodney L. White Center for Financial Research, University of Pennsylvania, Philadelphia, PA. 
Rosenbluth, Frances McCall, 1989, Financial politics in contemporary Japan, Cornell University Press, Ithaca, NY.

Schwert, G. William, 1989, Why does stock market volatility change over time?, Journal of Finance 44, 1115-1153.

Shleifer, Andrei, and Robert Vishny, 1986, Large shareholders and corporate control, Journal of Political Economy 94, 461-488.

Shleifer, Andrei, and Robert Vishny, 1997, A survey of corporate governance, Journal of Finance 52, 737-784.

Smith, Katherine, and George Sofianos, 1997, The impact of a NYSE listing on the global trading of non-US stocks, working paper 97-02, New York Stock Exchange, New York, NY.

Stulz, René M., 1981, On the effects of barriers to international asset pricing, Journal of Finance 25, 783-794.

Stulz, René M., 1990, Managerial discretion and optimal financing policies, Journal of Financial Economics 26, 3-27.

Stulz, René M., 1995a, Globalization and the cost of capital: The case of Nestlé, European Financial Management 8, 30-38.

Stulz, René M., 1995b, International portfolio choice and asset pricing: An integrative survey, in V. Maksimovic and W. Ziemba, eds., The Handbook of Modern Finance, North Holland.

Stulz, René M., 1997, International portfolio flows and securities markets, unpublished working paper, Dice Center for Financial Economics, The Ohio State University, Columbus, OH.

Subrahmanyam, Marti G., 1975, On the optimality of international capital market integration, Journal of Financial Economics 2, 3-28. 
Suzuki, Kazunori, 1997, Inter-corporate shareholders in Japan: Their significance and impact of sales of stakes, unpublished working paper, London School of Economics, London, UK.

Tesar, Linda, and Ingrid Werner, 1995, Home bias and high turnover, Journal of International Money and Finance 14, 467-493.

Tesar, Linda, and Ingrid Werner, 1998, The internationalization of securities markets since the 1987 crash, Brookings-Wharton Papers on Financial Services, 281-372.

Urias, M., 1994, The impact of security cross-listing on the cost of capital in emerging markets, working paper, Stanford University, Palo Alto, CA.

Zingales, Luigi, 1994, The value of the voting right: A study of the Milan stock exchange experience, Review of Financial Studies 7, 125-148. 


\section{Appendix}

1. Let $\sigma_{\mathrm{H}}$ be the volatility of return of the small country market portfolio, $\sigma_{\mathrm{W}}$ be the volatility of the return of the market portfolio for the rest of the world, and $\rho$ be the correlation coefficient between the two portfolios. Consider a portfolio with an investment of $w$ in the rest of the world and (1-w) in the small country. The portfolio has a volatility $\sigma_{\mathrm{P}}$ given by:

$$
\sigma_{P}^{2}=w^{2} \sigma_{W}^{2}+2(1-w) w \rho \sigma_{W} \sigma_{H}+(1-w)^{2} \sigma_{H}^{2}
$$

Taking the derivative with respect to $\mathrm{w}$ and setting $\mathrm{w}=0$ yields:

$$
\frac{d \sigma_{P}^{2}}{d w}=2 \sigma_{H}^{2}-2 \rho \sigma_{H} \sigma_{W}
$$

A necessary condition for an increase in $\mathrm{w}$ from the position of no foreign investment to decrease the volatility of the portfolio is that the above expression is positive, which is the condition given by equation (3).

2. Let RT be the relative risk tolerance, $h$ the fraction of investors that invest in their home country only, $\sigma_{\mathrm{H}}$ be the volatility of return of the small country, $\sigma_{\mathrm{W}}$ be the volatility of the rest of the world which is viewed as one country, $\delta$ the capitalization of the small country as a fraction of the world capitalization, $\mu_{D}$ the risk premium of the small country, $\mu_{W}$ the risk premium of the rest of the world. We assume zero correlation between the small country and the rest of the world. With constant relative risk tolerance and zero correlation, we have the following demands for the market portfolio of the small country: 


$$
\begin{aligned}
& w_{I}^{H} W_{I}^{H}=R T\left(\frac{\mu_{H}}{\sigma_{H}^{2}}\right) \delta h W \\
& w_{H}^{H} W_{I}^{H}=R T\left(\frac{\mu_{H}}{\sigma_{H}^{2}}\right) \delta(1-h) W \\
& w_{I}^{W} W_{I}^{W}=R T\left(\frac{\mu_{H}}{\sigma_{H}^{2}}\right)(1-\delta) h W
\end{aligned}
$$

where the demands for the small country market portfolio are, respectively, the demand from the small country investors without home bias, the demand from the small country investors with home bias, and the demand from the rest of the world without home bias. In equilibrium, these demands have to sum up to the market capitalization of the small country market:

$$
\begin{aligned}
& w_{I}^{H} W_{I}^{H}+w_{H}^{H} W_{I}^{H}+w_{I}^{W} W_{I}^{W}= \\
& R T\left(\frac{\mu_{H}}{\sigma_{H}^{2}}\right) \delta h W+R T\left(\frac{\mu_{H}}{\sigma_{H}^{2}}\right) \delta(1-h) W+R T\left(\frac{\mu_{H}}{\sigma_{H}^{2}}\right)(1-\delta) h W \\
& =M_{H}
\end{aligned}
$$

where $\mathrm{M}_{\mathrm{H}}$ is the capitalization of the small country market portfolio. Figure 6 represents the risk premium as a function of $\mathrm{h}$ taking all other variables as given. 
Table 1. Estimates of the cost of capital reduction due to globalization.

The table uses the Datastream weekly indices in dollars from $9 / 30 / 88$ to $10 / 28 / 98$ or since they became available. We denote by "Condition" the difference between the variance of the return of the country portfolio minus its covariance with the world market portfolio. Condition has to be positive from the analysis of Section I for the country to have a lower cost of capital in world markets rather than in autarky.

\begin{tabular}{|c|c|c|c|c|}
\hline & $\begin{array}{l}\text { Weekly return } \\
\text { standard deviation }\end{array}$ & $\begin{array}{l}\text { Weekly average } \\
\text { return }\end{array}$ & $\begin{array}{l}\text { Correlation with } \\
\text { world market } \\
\text { portfolio }\end{array}$ & Condition \\
\hline Argentina & 0.1635 & 0.0188 & 0.0460 & 0.0266024 \\
\hline Australia & 0.0254 & 0.0018 & 0.5160 & 0.0003978 \\
\hline Germany & 0.0268 & 0.0028 & 0.6450 & 0.0003897 \\
\hline Belgium & 0.0219 & 0.0028 & 0.6250 & 0.0002213 \\
\hline China & 0.1189 & 0.0101 & -0.0870 & 0.0143338 \\
\hline Chile & 0.0319 & 0.0039 & 0.2530 & 0.0008672 \\
\hline Canada & 0.0186 & 0.0016 & -0.0170 & 0.0003523 \\
\hline Denmark & 0.0249 & 0.0029 & 0.4750 & 0.0003951 \\
\hline Spain & 0.0293 & 0.0027 & 0.6640 & 0.0004913 \\
\hline Finland & 0.0337 & 0.0024 & 0.4570 & 0.0008429 \\
\hline France & 0.0257 & 0.0028 & 0.6540 & 0.0003437 \\
\hline Greece & 0.0464 & 0.0032 & 0.0280 & 0.0021245 \\
\hline Hongkong & 0.0432 & 0.0038 & 0.5050 & 0.0014521 \\
\hline Indonesia & 0.0765 & -0.0015 & 0.2990 & 0.0054153 \\
\hline Ireland & 0.0259 & 0.0032 & 0.5700 & 0.0003927 \\
\hline Italy & 0.0351 & 0.0024 & 0.4760 & 0.0009151 \\
\hline Japan & 0.0372 & -0.0004 & 0.7610 & 0.0008465 \\
\hline Korea & 0.0515 & -0.0005 & 0.2780 & 0.002383 \\
\hline Mexico & 0.0476 & 0.0061 & -0.0220 & 0.0022895 \\
\hline Malaysia & 0.0552 & 0.0017 & 0.4340 & 0.0025918 \\
\hline Netherland & 0.0213 & 0.0034 & 0.7300 & 0.0001595 \\
\hline Norway & 0.0338 & 0.0026 & 0.5430 & 0.0007978 \\
\hline New Zealand & 0.0283 & 0.0013 & 0.4460 & 0.0005645 \\
\hline Austria & 0.0305 & 0.0021 & 0.4800 & 0.0006532 \\
\hline Philippines & 0.0477 & 0.0021 & 0.3140 & 0.0019917 \\
\hline Poland & 0.0648 & -0.0023 & 0.3830 & 0.0037289 \\
\hline Portugal & 0.0279 & 0.0018 & 0.4730 & 0.0005308 \\
\hline South Africa & 0.0338 & 0.0012 & 0.4500 & 0.0008539 \\
\hline Sweden & 0.0309 & 0.0028 & 0.6180 & 0.0005945 \\
\hline Singapore & 0.0343 & 0.0018 & 0.5660 & 0.0008092 \\
\hline Switzerland & 0.0252 & 0.0034 & 0.6320 & 0.0003348 \\
\hline Taiwan & 0.0535 & 0.0027 & -0.0750 & 0.0029377 \\
\hline Thailand & 0.0589 & 0.0020 & 0.3500 & 0.0030768 \\
\hline Turkey & 0.0727 & 0.0051 & -0.0450 & 0.0053411 \\
\hline UK & 0.0226 & 0.0029 & 0.6780 & 0.0002228 \\
\hline USA & 0.0194 & 0.0033 & 0.6940 & 0.0001223 \\
\hline Venezuela & 0.0775 & 0.0045 & 0.0610 & 0.0059175 \\
\hline World & 0.0189 & 0.0019 & 1.0000 & \\
\hline
\end{tabular}


Table 2. Estimates of U.S. and foreign ownership for selected emerging markets.

The estimates for developed economies are for 1996 and from Tesar and Werner (1998). For emerging markets, the estimates of U.S. ownership are from Bekaert and Harvey (1997) who cumulate flow of funds data until the end of 1995 and the estimates of foreign ownership are from Campollo-Palmer (1997).

\begin{tabular}{|c|c|c|}
\hline & $\begin{array}{l}\text { U.S. ownership as percent of } \\
\text { market capitalization }\end{array}$ & $\begin{array}{l}\text { Foreign ownership as percent of } \\
\text { market capitalization }\end{array}$ \\
\hline \multicolumn{3}{|c|}{ Developed economies } \\
\hline Australia & $3.0 \%$ & \\
\hline Canada & 7.6 & \\
\hline France & 4.9 & \\
\hline Japan & 14.4 & \\
\hline Germany & 4.6 & \\
\hline Netherlands & 7.4 & \\
\hline Spain & 2.6 & \\
\hline Sweden & 3.9 & \\
\hline Switzerland & 3.9 & \\
\hline United Kingdom & 21.1 & \\
\hline \multicolumn{3}{|c|}{ Emerging markets } \\
\hline Argentina & 20 & $38 \%$ \\
\hline Brazil & 6 & \\
\hline Chile & 4 & 17 \\
\hline Columbia & 6 & 7 \\
\hline China & & 6 \\
\hline India & 2 & \\
\hline Indonesia & 6 & \\
\hline Malaysia & 1 & \\
\hline Mexico & 21 & 25 \\
\hline Peru & & 38 \\
\hline Thailand & 6 & \\
\hline Venezuela & 43 & 36 \\
\hline
\end{tabular}


Figure 1. Volatility of the portfolio of the investor from the small country with a small investment in the global equity markets.

This figure shows the volatility of the return of the portfolio of the small country investor, $\sigma_{\text {Portfolio, }}$ when the portfolio share of the global market is 0.10 . The volatility of the return of the market portfolio of the small country is assumed to be $25 \%$. $\sigma_{\text {Portfolio }}$ is shown as a function of the volatility of the world market portfolio, $\sigma_{\text {World }}$, and the correlation between the return of the small country market portfolio and the world market portfolio, $\rho_{\text {Small country,World }}$, where the world market portfolio does not include the small country market portfolio.

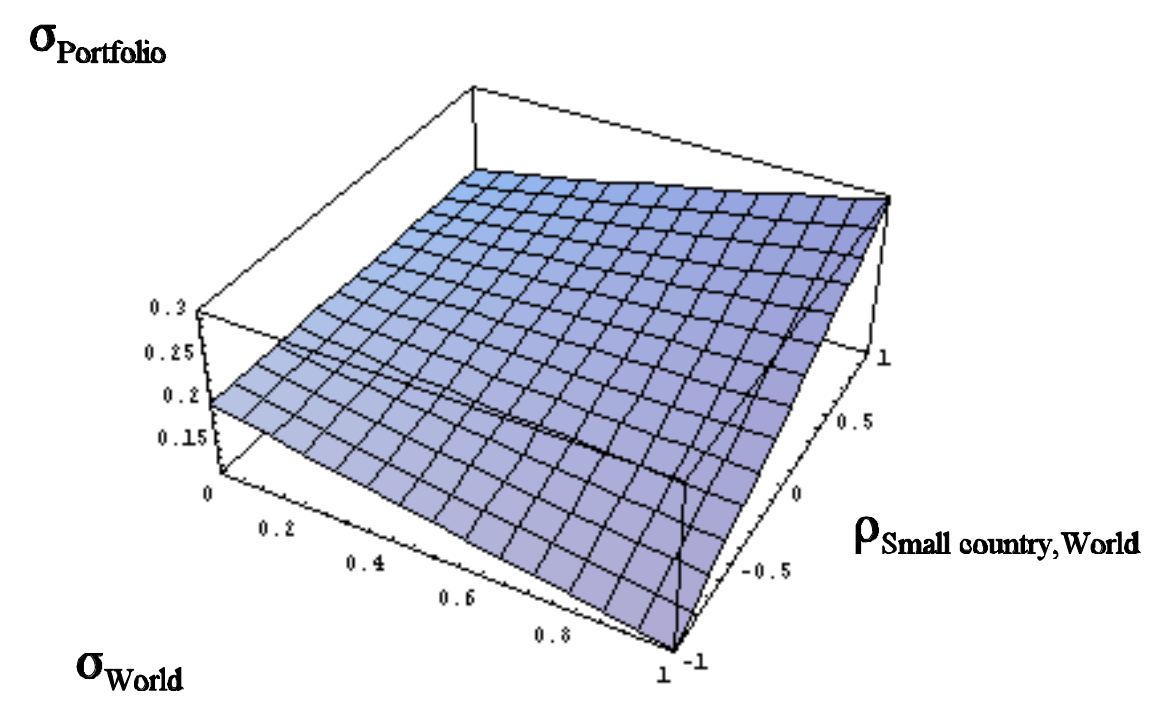


Figure 2. Maximum correlation coefficient required for globalization to decrease the cost of capital of the small country.

This figure shows the correlation coefficient, $\boldsymbol{\rho}_{\text {World after }}$, such that the cost of capital is the same when the small country is segmented from the global equity market and when it is integrated. The figure shows this correlation as a function of the volatility of the world market portfolio, $\sigma_{\text {World }}$, and of the volatility of the small country market portfolio, $\sigma_{\text {Small Country }}$. The distribution of the world market portfolio is taken to be fixed. Whenever the correlation coefficient is smaller, the cost of capital is lower when the small country is part of the global equity market.

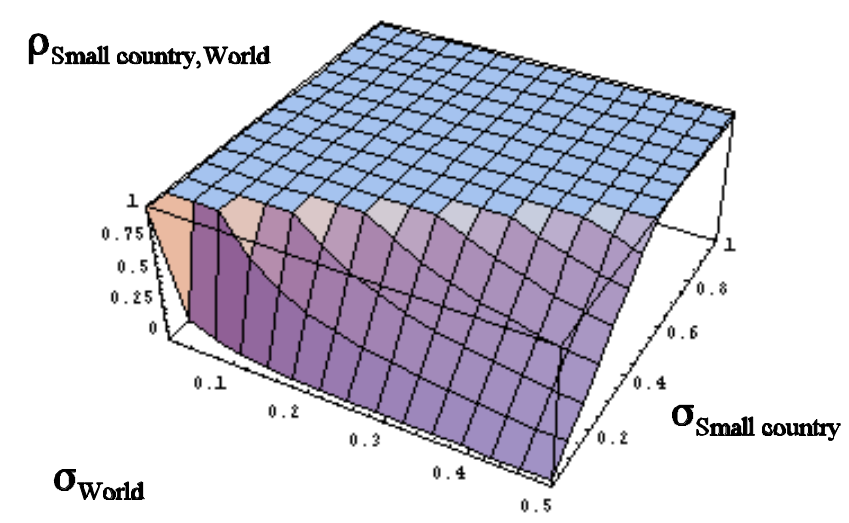


Figure 3. Impact on the volatility of the world market portfolio, $\sigma_{\text {World after }}$ of adding a country to the world market portfolio. We assume that the volatility of the world market portfolio before adding a country is $15 \%$. The old market portfolio represents $90 \%$ of the new one, so that the new country has a weight of $10 \%$ in the new market portfolio. We express $\sigma_{\text {World after }}$ as a function of the volatility of the small country market portfolio, $\sigma_{\text {Small country }}$ and the correlation between the small country market portfolio and the world market portfolio before the addition, $\rho_{\text {Small country,World before }}$.

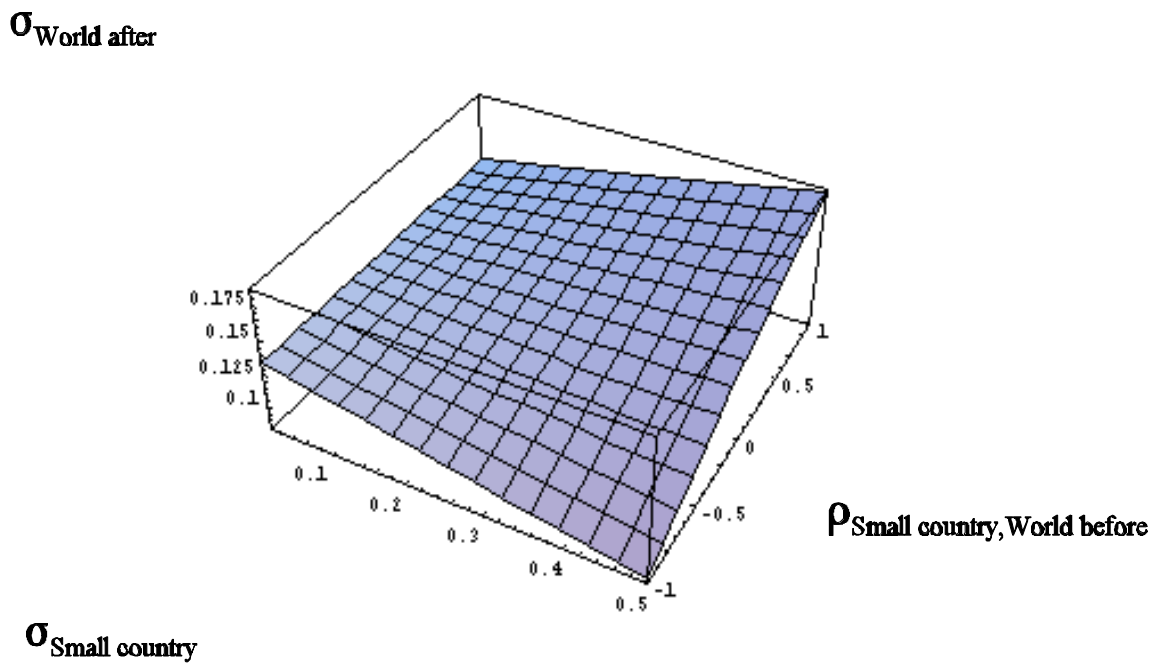


Figure 4. Word portfolio return volatility

This volatility is computed monthly from daily returns of the Datastream world portfolio using the approach proposed by Schwert (1989).

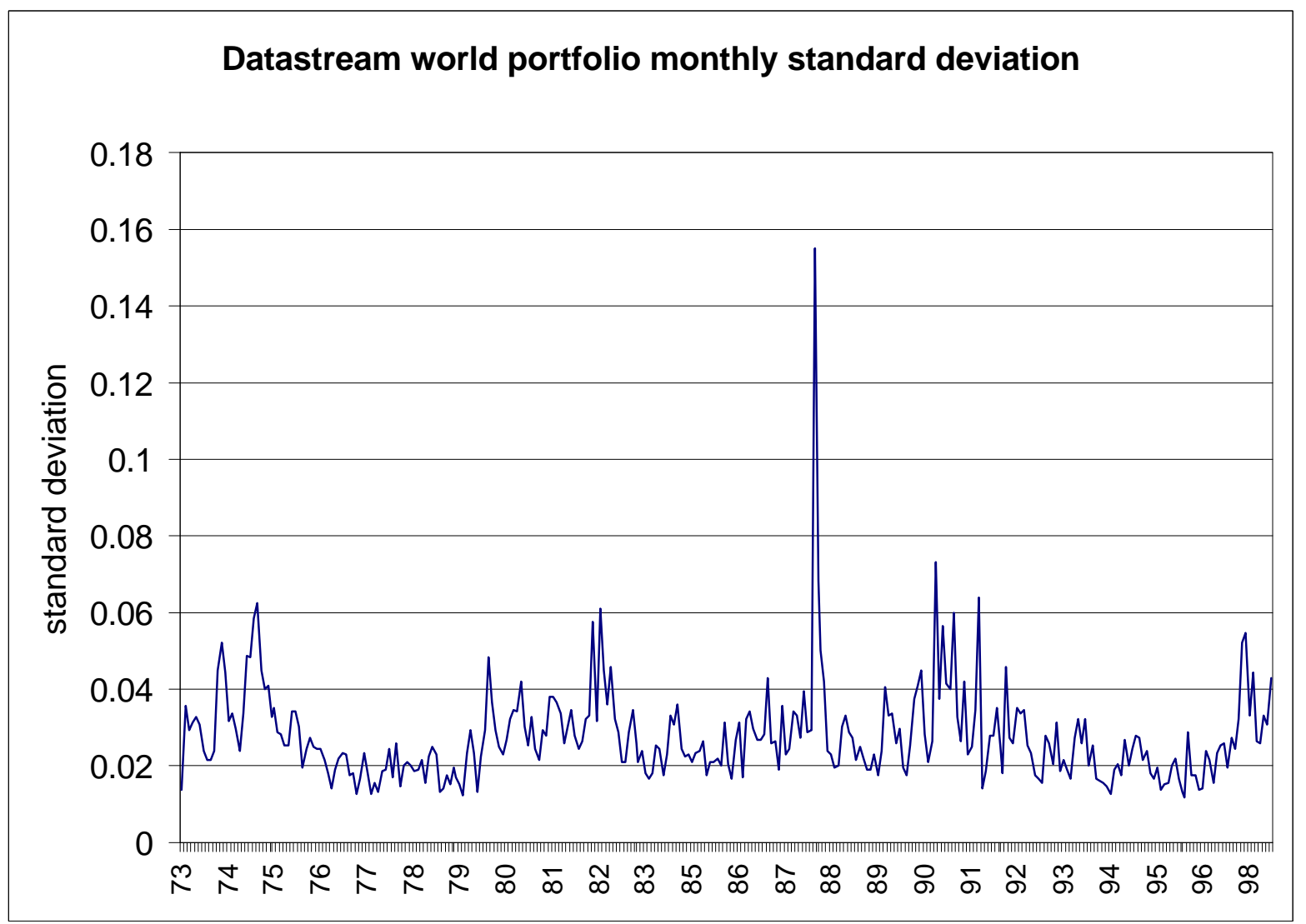




\section{Figure 5. The cost of capital after liberalization.}

This figure shows the cost of capital after liberalization, $\mathrm{r}_{\text {After }}$, given a $30 \%$ increase in market capitalization as a result of liberalization, as a function of the dividend growth rate, $\mathrm{g}$, and the cost of capital before liberalization, $\mathrm{r}_{\text {Before }}$.

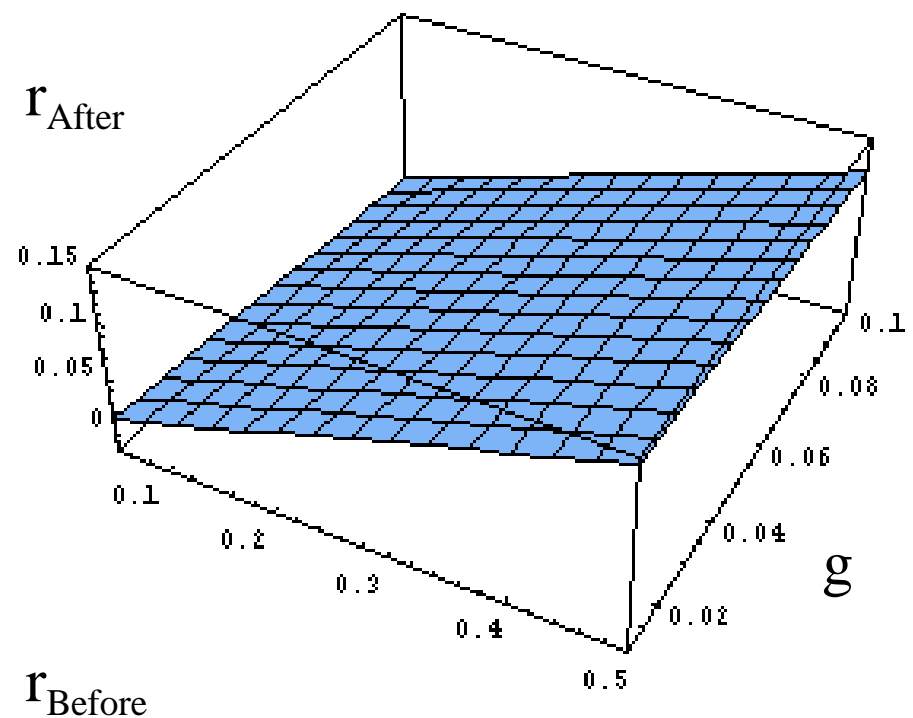




\section{Figure 6. Home bias and the cost of capital.}

This figure shows the relation between the risk premium of the local market, $\mu_{\text {Local }}$, and the fraction of investors who invest at home only, $\mathrm{h}$, assuming that the volatility of the local market is $30 \%$, that the local market is uncorrelated with the world market, that the local market is $10 \%$ of the world equity capitalization, and that the coefficient of relative risk tolerance is 2 .

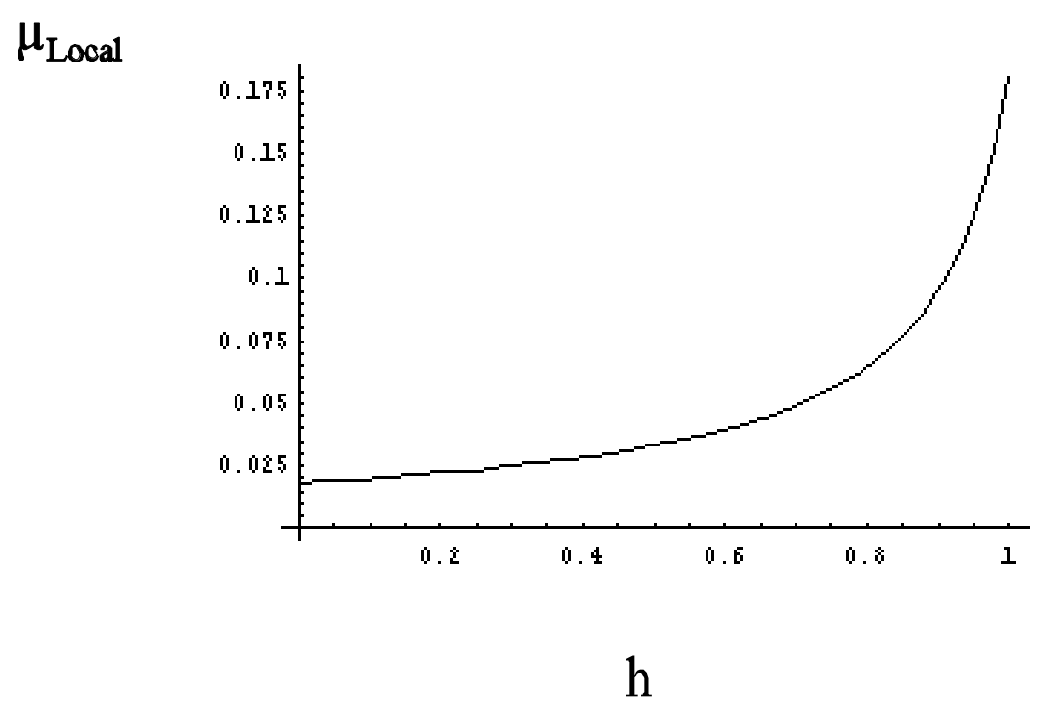

